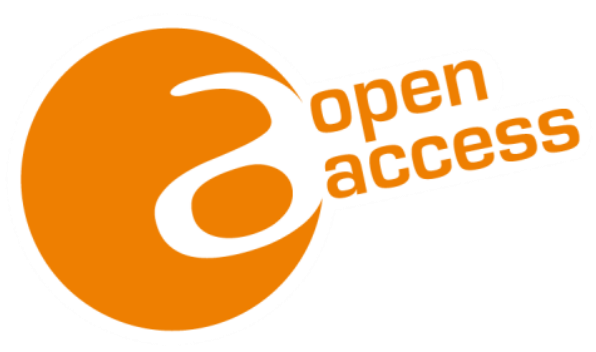

\title{
INTERNATIONAL STANDARD CLASSIFICATION OF EDUCATION
}

Fields of education and training 2013 (ISCED-F 2013) Detailed field descriptions 


\section{UNESCO}

The constitution of the United Nations Educational, Scientific and Cultural Organization (UNESCO) was adopted by 20 countries at the London Conference in November 1945 and entered into effect on 4 November 1946. The Organization currently has 195 Member States and 9 Associate Members.

The main objective of UNESCO is to contribute to peace and security in the world by promoting collaboration among nations through education, science, culture and communication in order to foster universal respect for justice, the rule of law, and the human rights and fundamental freedoms that are affirmed for the peoples of the world, without distinction of race, sex, language or religion, by the Charter of the United Nations.

To fulfil its mandate, UNESCO performs five principal functions: 1) prospective studies on education, science, culture and communication for tomorrow's world; 2) the advancement, transfer and sharing of knowledge through research, training and teaching activities; 3 ) standard-setting actions for the preparation and adoption of internal instruments and statutory recommendations; 4) expertise through technical co-operation to Member States for their development policies and projects; and 5) the exchange of specialised information.

UNESCO is headquartered in Paris, France.

\section{UNESCO Institute for Statistics}

The UNESCO Institute for Statistics (UIS) is the statistical office of UNESCO and is the UN depository for global statistics in the fields of education, science and technology, culture and communication.

The UIS was established in 1999. It was created to improve UNESCO's statistical programme and to develop and deliver the timely, accurate and policy-relevant statistics needed in today's increasingly complex and rapidly changing social, political and economic environments.

The UIS is based in Montreal, Canada.

Published in 2015 by:

UNESCO Institute for Statistics

P.O. Box 6128, Succursale Centre-Ville

Montreal, Quebec H3C 3J7

Canada

Tel: $\quad+1-514-343-6880$

Email: uis.publications@unesco.org

http://www.uis.unesco.org

CUNESCO-UIS 2015

ISBN 978-92-9189-179-5

Ref: UIS/2015/INS/6

DOI http://dx.doi.org/10.15220/978-92-9189-179-5-en

This publication is available in Open Access under the Attribution-ShareAlike 3.0 IGO (CC-BY-SA 3.0 IGO) license (http://creativecommons.org/licenses/by-sa/3.0/igo/). By using the content of this publication, the users accept to be bound by the terms of use of the UNESCO Open Access Repository (http://www.unesco.org/open-access/terms-use-ccbysa-en).

The designations employed and the presentation of material throughout this publication do not imply the expression of any opinion whatsoever on the part of UNESCO concerning the legal status of any country, territory, city or area or of its authorities or concerning the delimitation of its frontiers or boundaries. 


\section{Contents}

Page

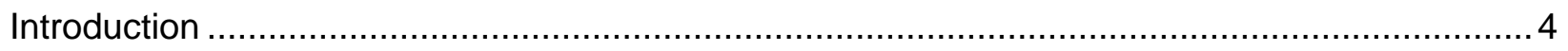

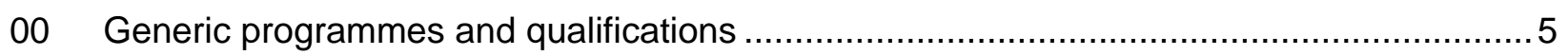

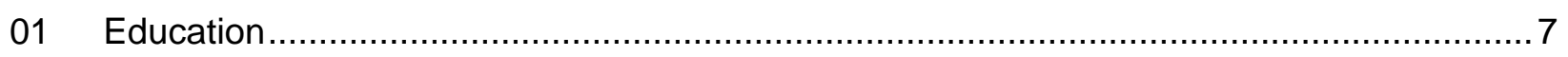

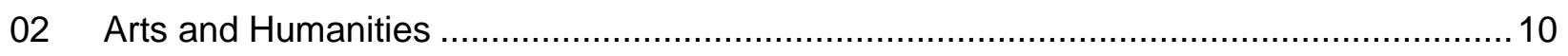

03 Social Sciences, Journalism and Information …….....................................................

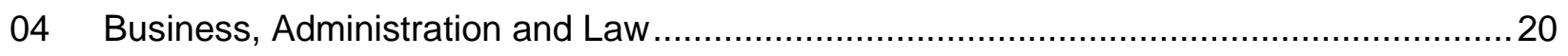

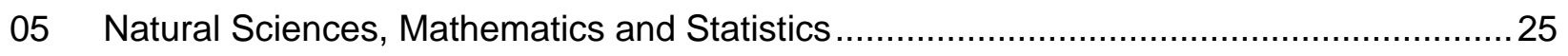

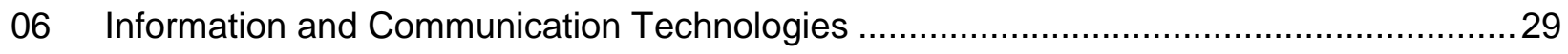

07 Engineering, Manufacturing and Construction...........................................................

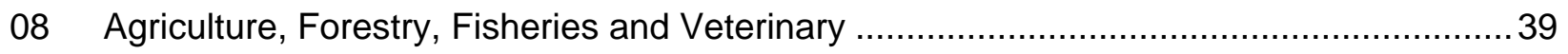

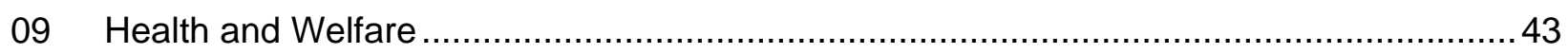

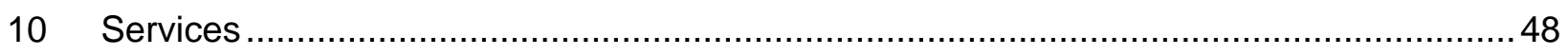

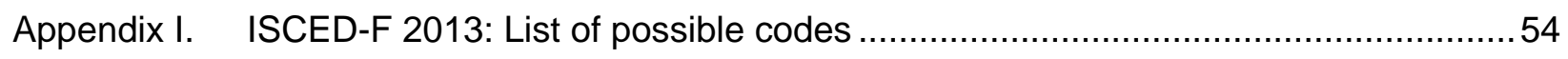

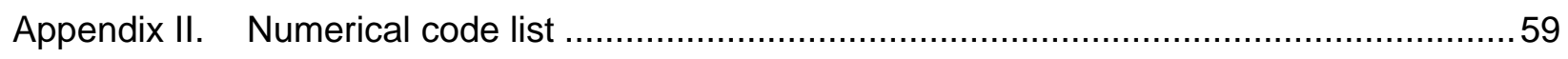

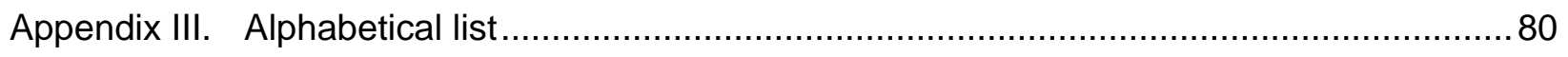




\section{Introduction}

The International Standard Classification of Education (ISCED) is a framework for assembling, compiling and analysing cross-nationally comparable statistics on education. ISCED is a member of the United Nations International Family of Economic and Social

Classifications and is the reference classification for organizing education programmes and related qualifications by levels and fields of education. First developed in the mid-1970s by the United Nations Educational, Scientific and Cultural Organization (UNESCO), ISCED has been revised several times, including in both 2011 and 2013.

The revision in 2011, concentrated primarily on changes to the levels of education of programmes (ISCED-P) and introduced, for the first time, a classification of levels of educational attainment based on qualifications (ISCED-A). The 2013 revision focused on the fields of education and training (ISCED-F). The ISCED revisions arethe product of international agreement and are adopted formally by the General Conference of UNESCO Member States.

The current document describes the subject content of each of the detailed fields of the 2013 revision of the ISCED Fields of Education and Training classification (ISCED-F 2013). Where possible each description gives examples both of subjects which belong to each field and some boundary cases which are included in other fields. Such exclusions help to better distinguish one field from another especially where the content of two fields appears to be similar.

At the end of the document there are alphabetical and numerical listings of subjects and fields. These lists include more examples of subjects than are mentioned in the field descriptions themselves.

A summary of all possible field codes and their place in the classification hierarchy is also included. 


\section{Generic programmes and qualifications}

Generic programmes and qualifications are those providing fundamental and personal skills education which cover a broad range of subjects and do not emphasise or specialise in a particular broad or narrow field.

This broad field should not be used as a residual category. Programmes and qualifications with a specific subject emphasis should be classified in broad fields 01 to 10 . In particular, education at the tertiary level should only by way of exception be classified here.

\section{Basic programmes and qualifications}

\section{Basic programmes and qualifications}

Basic programmes and qualifications are designed to provide participants with fundamental skills in reading, writing and arithmetic along with an elementary understanding of other subjects such as history, geography, natural science, social science, art and music, and in some cases religious instruction. These programmes and qualifications are normally offered at primary and lower secondary levels. Broad, non-specialised programmes at upper secondary level are also classified here even if there is some concentration on, for example, humanities, social science, natural science etc. Vocational programmes and qualifications are included here only by way of exception.

Programmes and qualifications with the following main subject content are classified here:

Basic programmes and qualifications

Broad, generic (non-specialised) programmes and qualifications

General programmes and qualifications with no specific subject emphasis

Programmes and qualifications at primary level

$\underline{\text { Inclusions }}$

Basic programmes and qualifications at upper secondary level (in some countries at lower secondary level) with some emphasis on e.g. humanities, social sciences or natural sciences but still covering other fields of knowledge are included in this detailed field. In some countries such programmes or qualifications are offered on a modular basis and should also be classified here.

\section{Exclusions}

Programmes that are considered as general in the programme orientation sense (nonvocational) but have a clear emphasis on a detailed, narrow or broad field are excluded from this detailed field and included in one of the broad fields 01-10, depending on the subject covered. 


\section{Literacy and numeracy}

\section{Literacy and numeracy}

Literacy and numeracy are programmes or qualifications arranged mainly for adults, designed to teach fundamental skills in reading, writing and arithmetic. The typical age range of participants can be used to distinguish between detailed field 0011 'Basic programmes and qualifications' and this detailed field.

Programmes and qualifications with the following main content are classified here:

Basic remedial programmes for youth or adults

Literacy

Numeracy

\section{Personal skills}

\section{$0031 \quad$ Personal skills}

Personal skills are defined by reference to the effects on the individual's capacity (mental, social etc.). This detailed field covers personal skills programmes not included in 0011 'Basic programmes and qualifications' or 0021 'Literacy and numeracy', giving key competencies and transferable skills.

Programmes and qualifications with the following main content are classified here:

Argumentation and presentation

Assertiveness training

Communication skills

Co-operation

Development of behavioural capacities

Development of mental skills

Job-seeking programmes

Parenting courses

Public speaking

Self-esteem skills

Social competence

Time management

\section{$\underline{\text { Inclusions }}$}

Education and training in leadership in the context of personal development is included here.

Education and training related to the work place or to work assignments is included in this detailed field if it has more to do with personal development than work development. Personal skills courses can be taught at the workplace, but still be classified here based on their content.

Programmes for people with special needs on how to cope with their daily life are included here

\section{Exclusions}

Study of leadership in the context of management is excluded from this group and included in detailed field 0413 'Management and administration'. 


\section{Education}

\section{Education}

\section{Education science}

Education science is the study of the learning process and the theories, methods and techniques of imparting knowledge to others.

Programmes and qualifications with the following main content are classified here:

Curriculum studies

Didactics

Educational assessment, testing and measurement

Educational evaluation and research

Paedagogical sciences

\section{Exclusions}

Teacher training programmes which combine education science with the practice of teaching are excluded from this detailed field and included in one of the detailed fields for teacher training (0112-0114).

\section{Training for pre-school teachers}

Training for pre-school teachers is the study of the theories, methods and practice of teaching very young children up to 7 years of age within formal school settings at pre-primary or early childhood educational development levels.

Programmes and qualifications with the following main content are classified here:

Early childhood teaching (within formal school settings)

Pre-primary teacher training

\section{Exclusions}

Training in caring for children outside formal school settings is excluded from this detailed field and included in detailed field 0922 "Child care and youth services"

\section{Teacher training without subject specialisation}

Training for teachers without subject specialisation is the study of the theories, methods and practice of providing children between approximately 5 and 15 years of age with the fundamental skills in reading, writing and mathematics along with an elementary understanding of other subjects such as history, geography, social science etc. and laying the foundation for lifelong learning. Subject specialisation is stressed less than in detailed field 0114 'Teacher training with subject specialisation'. The study of teaching children with special needs is included in this detailed field, likewise the study of teaching adults fundamental reading and writing skills and teaching immigrants these types of skills in their home or first language. 
Programmes and qualifications with the following main content are classified here:

Class teacher training

Indigenous teacher training

Primary teaching

Teacher training for children with special needs

$\underline{\text { Inclusions }}$

The study of teaching adults basic literacy and numeracy skills is included here. Teacher's aide (teaching assistant) is also included here.

\section{Exclusions}

Teacher training with subject specialisation even if intended for the teaching of children in primary or lower secondary education is excluded from this detailed field and included in detailed field 0114 'Teacher training with subject specialisation'.

\section{Teacher training with subject specialisation}

Teacher training with subject specialisation is the study of the theories, methods and practice of teaching a specific subject, mostly at secondary or higher levels of education. Programmes and qualifications included in this detailed field often comprise both studies as well as the subject/subjects that are going to be taught.

Programmes and qualifications with the following main content are classified here:

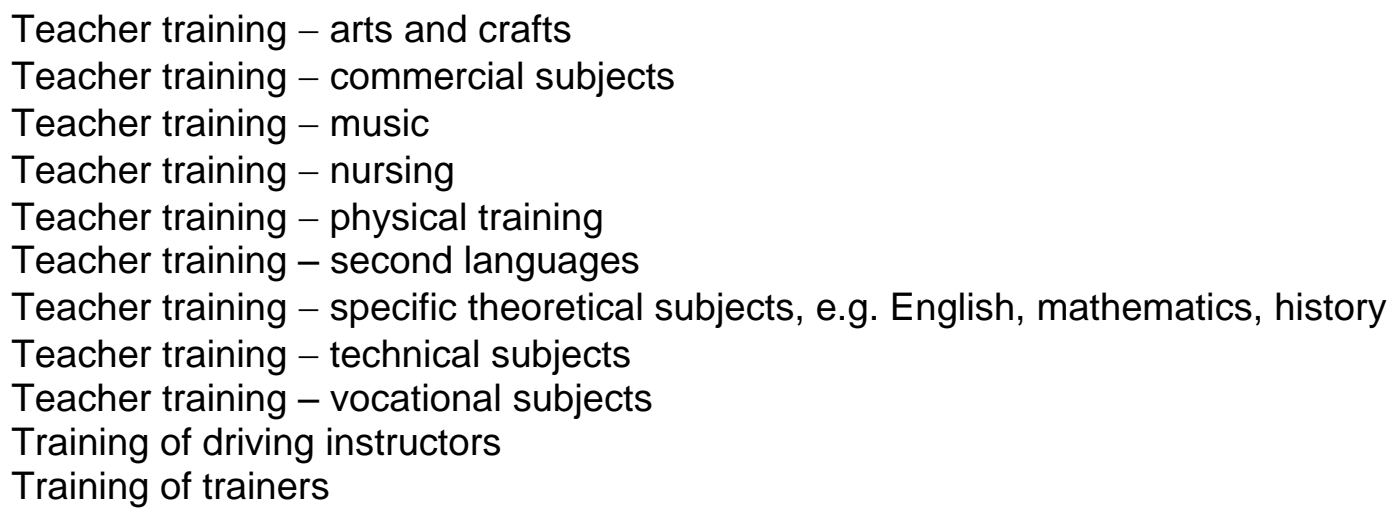

$\underline{\text { Inclusions }}$

Teacher training courses for university teachers, instructors of work place and working life skills and in practical and artistic subjects are included here.

\section{Exclusions}

Training of sports trainers is excluded from this detailed field and included in detailed field 1014 'Sports'. 
018 Inter-disciplinary programmes and qualifications involving education

0188 Inter-disciplinary programmes and qualifications involving education

Inter-disciplinary programmes and qualifications to which the greatest intended learning time is devoted to education are classified here. 


\section{Arts and Humanities}

\section{Arts}

\section{Audio-visual techniques and media production}

Audio-visual techniques and media production is the study of techniques and skills to produce books or newspapers, radio or TV production, film or video production, recorded music production and graphic reproduction. It includes programmes and qualifications in methods of colour reproduction, photography and computer graphics. Study of combining pictures, words and decorations in the production of books, magazines, posters, adverts etc. is also included.

Programmes and qualifications with the following main content are classified here:

Animation

Bookbinding

Camera operating

Compositing (printing)

Computer game production

Computer type-setting

Film and video production

Graphic design

Graphic reproduction

Illustration

Interactive media design

Media techniques

Multimedia production

Photography

Pre-press operations

Print finishing and binding

Printing

Publishing design, lay-out

Radio and TV production

Recorded music production

Sound techniques

Type-setting

$\underline{\text { Inclusions }}$

Desktop publishing and lay-out are included here.

\section{Exclusions}

Programmes and qualifications in the use of specific software applications for desktop publishing and website development are excluded from this detailed field and included in detailed field 0611 'Computer use".

Study of journalism (wording and content of messages) is excluded from this detailed field and included in detailed field 0321 'Journalism and reporting'. 


\section{Fashion, interior and industrial design}

Fashion, interior and industrial design is the study of creatively combining line, form and fabric in designing and constructing e.g. fashion garments, industrial products and interiors.

Programmes and qualifications with the following main content are classified here:

Costume design

Design of industrial products

Fashion design

Interior architecture

Interior design

Stage designing

Window dressing

\section{Exclusions}

Study of Building design is excluded from this detailed field and included in detailed field 0731 'Architecture and town planning'.

Study of Industrial design is excluded from this detailed field if emphasis is given to technical subjects and not to artistic design, and included in the appropriate detailed field under 071 'Engineering and engineering trades'.

Publishing design and graphic design are excluded from this detailed field and included in detailed field 0211 'Audio-visual techniques and media production'.

\section{Fine arts}

Fine arts is the study of visual forms of creative expression, dealing with theory, history, techniques, performance and production in fine arts.

Programmes and qualifications with the following main content are classified here:

Art theory

Calligraphy

Etching

Fine art printmaking

History of art

Painting

Philosophy of art

Sculpture

\section{Exclusions}

Training in ceramics, pottery etc is excluded from this detailed field and included in detailed field 0214 'Handicrafts'.

Study of architecture is excluded from this detailed field and included in detailed field 0731 'Architecture and town planning'.

Teacher training in arts is excluded from this detailed field and included in detailed field 0114 'Teacher training with subject specialisation'. 


\section{Handicrafts}

Handicrafts is the study of techniques and skills in a chosen craft, such as jewellery, pottery, weaving, woodcarving etc.

Programmes and qualifications with the following main content are classified here:

Ceramics

Crafts, folk arts and artisan

Decorative metal crafts

Indigenous crafts

Embroidery

Floristry (flower arranging)

Glass arts and craft

Goldsmithing

Jewellery

Making of musical instruments (not industrial)

Musical instruments (repairing and tuning)

Silversmithing

Stone carving (craft)

Weaving (craft)

Woodcarving

\section{Exclusions}

Study of industrial (large scaled mechanised) production of pottery, woven materials, embroidery etc. is excluded from this field and included in one of the detailed fields under broad field 07 'Engineering, manufacturing and construction'.

\section{Music and performing arts}

Music and performing arts is the study of the principles and techniques associated with performance involving music, speech, movement, mime, characterisation, improvisation and stage craft.

Programmes and qualifications with the following main content are classified here:

Acting and directing

Ballet

Choreography

Circus

Composition (music)

Conducting (music)

Creative and performance art

Dance

Drama

History of film and theatre

History of music

Music

Music conducting

Musicology

Theatre/Theatre sciences 
$\underline{\text { Inclusions }}$

Study of music and performing arts history and theory is included here.

Exclusions

Teacher training in music and other performing arts is excluded from this detailed field and included in detailed field 0114 'Teacher training with subject specialisation'.

\section{Humanities (except languages)}

\section{Religion and theology}

Religion and theology is the study of religious beliefs, concepts, symbols, expressions and texts of spirituality.

Programmes and qualifications with the following main content are classified here:

Religious history

Study of sacred books

Study of different religions

Theology

$\underline{\text { Inclusions }}$

Included in this detailed field are programmes for children and young people, usually given in religious schools or seminars, in monasteries etc., aiming to develop an interest in the tenets of their religion and sufficient familiarity with its philosophy to assist in the propagation of their faith.

\section{Exclusions}

Basic programmes given in religious schools, seminars etc. containing religious instruction but not emphasising it or leading to a religious vocation, are excluded from this detailed field and included in 0011 'Basic programmes and qualifications'. Islamic sharia programmes and qualifications are excluded from this detailed field and included in detailed field 0421 'Law'.

\section{History and archaeology}

History is the study of past events, especially the political, social and economic development of a country, a continent or the world. History of medicine is classified here, likewise the study of history of science and ideas. Archaeology is the study of ancient civilisations by scientific analysis of what is found in the ground.

Programmes and qualifications with the following main content are classified here:

Archaeology

Cultural history

Folklore studies

History

History of literature

History of medicine

History of science and ideas

History of technology 
$\underline{\text { Inclusions }}$

Restoration and preservation of artistic heritage are included here.

Exclusions

Study of literature combined with study of a specific language is excluded from this detailed field and included in detailed field 0232 'Literature and linguistics'.

Study of classical languages (Latin etc.) is excluded from this detailed field and included in detailed field 0231 'Language acquisition'.

Study of History of art is excluded from this detailed field and included in detailed field 0213 'Fine arts'.

Study of Music and performing arts history is excluded from this detailed field and included in detailed field 0215 'Music and performing arts'.

Study of Economic history/history of economics is excluded from this detailed field and included in detailed field 0311 'Economics'.

\section{Philosophy and ethics}

Philosophy and ethics is the study of philosophy, ethics and related subjects dealing with the conception of life.

Programmes and qualifications with the following main content are classified here:

Ethics

Logic

Morals

Philosophy

\section{Exclusions}

Study of religion is excluded from this detailed field and included in detailed field 0221 'Religion'.

Study of Philosophy of arts is excluded from this detailed field and is included in detailed field 0213 'Fine arts'

\section{Languages}

\section{Language acquisition}

Language acquisition is the study of the structure and composition of languages taught as second or foreign languages (i.e. that are intended for non-native or non-fluent speakers of the language). It includes the study of related cultures, literature, linguistics and phonetics if related to the specific language being acquired and forms part of the same programme or qualification. Classical or dead languages are included here as it is assumed there are no native speakers of the language and hence the manner of teaching and the content of the curriculum are more similar to the teaching of foreign languages. 
Programmes and qualifications with the following main content are classified here:

Classical languages

Exogenous languages

Foreign languages

Interpretation

Phonetics

Second languages, for example English as a second language

Sign language

Sign language interpreting

Translation

\section{Inclusions:}

Language and linguistics studies are included here if the linguistics are related to a specific language or languages being acquired and forming part of the same programme or qualification. Translation and interpretation are included here.

\section{Exclusions:}

The study of the mother tongue or first language (i.e. that are intended for native, fluent or competent speakers of the language), even if this language is not a national language of the country of study (e.g. programmes for immigrants learning their mother tongue) are excluded from this detailed field and included in detailed field 0232 'Literature and linguistics'.

\section{Literature and linguistics}

Literature and linguistics is here defined as the study of language(s) intended for native, fluent or competent speakers of the language. It includes the study of related literature and linguistics and may or may not include the structure and composition of the language.

Programmes and qualifications with the following main content are classified here:

Creative writing

First language

Indigenous languages

Linguistics

Literature

"Mother tongue" languages

Native first languages

\section{$\underline{\text { Inclusions }}$}

Languages taught as the first language ("mother tongue"), even if the language is not the national language of the country of study (e.g. programmes for immigrants in their home or first language) are included here. Local and regional languages are included here if they are first languages spoken by a significant minority in the country and are intended for at least competent speakers of the language.

Study of comparative literature is included here. Study of general linguistics (not related to the study of a particular language) is included here. Study of literature in general (not combined with study of a special language) is included here. 


\section{Exclusions}

Language programmes are excluded from this detailed field if the language is taught as a foreign or a second language, and are then included in 0231 'Language acquisition'.

Programmes in literacy and numeracy are excluded from this detailed field and included in detailed field 0021 'Literacy and numeracy'.

Sign language programmes are excluded from this detailed field and included in detailed field 0231 'Language acquisition'.

028 Inter-disciplinary programmes and qualifications involving arts and humanities 0288 Inter-disciplinary programmes and qualifications involving arts and humanities

Inter-disciplinary programmes and qualifications to which the greatest intended learning time is devoted to arts and humanities are classified here. 


\section{Social Sciences, Journalism and Information}

\section{Social and behavioural sciences}

\section{Economics}

Economics is the study of economic policy, economic theory and economic decisionmaking.

Programmes and qualifications with the following main content are classified here:

Econometrics

Economic history

Economics

Political economics

\section{Exclusions}

Study of economics where emphasis is given to business studies is excluded from this detailed field and classified under 041 'Business and administration'. Study of home economics is excluded from this detailed field and included in the detailed field 1011 'Domestic services'.

\section{Political sciences and civics}

Political sciences and civics is the study of government and political principles or practice. The study of the rights and duties of the citizens are included here.

Programmes and qualifications with the following main content are classified here:

Civics

Human rights

International relations

Peace and conflict studies

Political history

Political science

Public policy studies

\section{Exclusions}

Study of political economics is excluded from this detailed field and included in the detailed field 0311 'Economics'.

\section{Psychology}

Psychology is the study of the human mind and behaviour as a result of individual differences, experience and environment.

Programmes and qualifications with the following main content are classified here:

Cognitive science

Psychoanalysis

Psychology

Psychotherapy 


\section{Sociology and cultural studies}

Sociology and cultural studies is the study of human beings and the way they behave in groups and in relation to society. The study of ethnology and social anthropology are included here, likewise the study of human and social geography.

Programmes and qualifications with the following main content are classified here:

Criminology

Cultural geography

Cultural studies

Demography/population studies

Ethnology

Gender studies

Social anthropology

Sociology

\section{Exclusions}

Social welfare where emphasis is given to practical social work is excluded from this detailed field and included in detailed field 0923 'Social work and counselling'.

Physical geography is excluded from this detailed field and included in detailed field 0532 'Earth science'.

\section{Journalism and information}

\section{Journalism and reporting}

Journalism and reporting is the study of the theory and practices of journalism/reporting as part of the field of mass communication. Journalism and reporting is about the wording and content of messages. It comprises news reporting, writing commentaries and feature stories of public interest etc.

Programmes and qualifications with the following main content are classified here:

Broadcast journalism

Editing

Information (wording and content)

Journalism

Mass communication (wording and content)

News reporting

\section{Exclusions}

Study of techniques for mass communication (e.g. printing and radio/TV production) is excluded from this detailed field and included in detailed field 0211 'Audio-visual techniques and media production'.

Study of lay-out and publishing design is excluded from this detailed field and included in detailed field 0211 'Audio-visual techniques and media production'. 
Study of public relations is excluded from this detailed field and included in detailed field 0414 'Marketing and advertising'.

\section{Library, information and archival studies}

Library, information and archival studies is the study of the methods of selecting, acquiring, organizing and storing collections of information, and facilitating the use of information. Museum and library studies are included here.

Programmes and qualifications with the following main content are classified here:

Archival sciences

Curatorial studies

Documentation

Information science

Library studies

Museum documentation

Museum studies

Museology

\section{Exclusions}

Restoration and preservation of artistic heritage are excluded from this field and included in field 0222 'History and archaeology'.

038 Inter-disciplinary programmes and qualifications involving social sciences, journalism and information

0388 Inter-disciplinary programmes and qualifications involving social sciences, journalism and information

Inter-disciplinary programmes and qualifications to which the greatest intended learning time is devoted to social sciences, journalism and information are classified here. 


\section{Business, Administration and Law}

\section{Business and administration}

\section{Accounting and taxation}

Accounting and taxation is the study of maintaining, auditing and recording financial transactions.

Programmes and qualifications with the following main content are classified here:

Accounting

Auditing

Bookkeeping

Tax accounting

Tax management

\section{Exclusions}

Study of tax laws is excluded from this detailed field and included in detailed field 0421 'Law'.

\section{Finance, banking and insurance}

Finance, banking and insurance is the study of planning, directing, organizing and controlling financial activities and services. It includes the control and monitoring of the financial resources of organizations, institutions and individuals, and the provision of financial services at the corporate and individual level.

Programmes and qualifications with the following main content are classified here:

Bank teller studies

Banking and finance

Finance theory

Insurance

Investment analysis

Investments and securities

Pension insurance

Social insurance

Stock-broking

\section{Exclusions}

Study of actuarial science is excluded from this detailed field and included in detailed field 0542 'Statistics'.

\section{Management and administration}

Management and administration is the study of planning, directing and operating the functions and activities of organizations and institutions. Programmes in management also including administration, economics, finance etc. are included here if emphasis is given to management and administration. 
Programmes and qualifications with the following main content are classified here:

Administration

Educational management

Employment management

Entrepreneurship

Health administration

Logistic management

Management science

Office management

Organizational theory and behaviour

Personnel administration

Personnel management

'Start your own business' courses

Supply change management

Training management

Inclusions:

Study of leadership in the context of management is included here.

\section{Exclusions:}

Training in leadership in the context of personal development is excluded from this detailed field and included in detailed field 0031 'Personal skills'.

Study of administration in the meaning of office work is excluded from this detailed field and included in detailed field 0415 'Secretarial and office work'.

\section{Marketing and advertising}

Marketing and advertising is the study of promoting the exchange processes of goods and services between organizations and/or individuals, and the study of consumer behaviour and requirements. It includes the study of the role of product development, pricing, distribution, promotion and sales in order to maximise business performance.

Programmes and qualifications with the following main content are classified here:

Advertising

Consumer behaviour

Market research

Marketing

Merchandising

Public relations 


\section{Secretarial and office work}

Secretarial and office work is the study of administrative procedures and practices, office technology and clerical, shorthand and keyboard skills. Specialised secretarial programmes (bilingual, medical, law, accounting etc) are included if the programme has secretarial work as its objective, rather than work as specialised assistants.

Programmes and qualifications with the following main content are classified here:

Administrative and secretarial services

Clerical programmes

Data entry

Foreign language secretary programmes

Keyboard skills

Legal secretary programmes

Medical secretary programmes

Operation of office equipment

Receptionist training

Secretarial programmes

Shorthand

Switchboard operating

Typing

$\underline{\text { Inclusions }}$

Broad secretarial programmes comprising among other things computer courses are included here.

\section{Exclusions}

Separate programmes or qualifications in using a specific computer software are excluded from this detailed field and included under detailed field 0611 'Computer use".

Office management is excluded from this detailed field and included in detailed field 0413 'Management and administration'.

Hotel receptionist programmes are excluded from this detailed field and included in detailed field 1013 'Hotel, restaurant and catering'.

\section{Wholesale and retail sales}

Wholesale and retail sales is the study of buying and selling goods and services, including stock management, pricing practices, loss prevention, sales systems and procedures. It includes the study of the workings and current trends of the wholesale and retail industries. Selling of buildings and properties is also included. 
Programmes and qualifications with the following main content are classified here:

Auctioneering

Consumer services

Demonstration techniques

Purchasing

Real-estate business

Retailing

Stock-keeping

Ware-housing

Wholesaling

$\underline{\text { Inclusions }}$

Study of buying and selling buildings and properties is included here.

\section{Work skills}

Work skills is the study of the structure and function of working life. It comprises programmes, mainly given as staff training, related to the working place and to work assignments.

Programmes and qualifications with the following main content are classified here:

Clients' needs

Company knowledge

Customer service training

'Introduction to work' courses

Organization at work

Quality assurance

Trade union courses (general)

Work development

Inclusions

Staff training related to the work place or work assignments is included here.

\section{Exclusions}

Training related to the work place or work assignments is excluded from this detailed field if it has more to do with personal development than work development and is included in detailed field 0031 'Personal skills'.

Staff training which can be classified to any other field is excluded from this detailed field and included in the appropriate field (e.g. quality courses should, if technical, be included in the detailed fields under 071 'Engineering and engineering trades'.)

Programmes in work environment should be included in detailed field 1022 'Occupational health and safety'.

Programmes, mostly at tertiary level, dealing with working life in general in terms of the labour market, the social partners, industrial psychology etc. are excluded from this detailed field and included in the detailed fields under 031 'Social and behaviour sciences'. 


\section{Law}

\section{Law}

Law is the study of the principles and procedures for formally maintaining social order, including training for legal professions such as advocate or training for the judicial bench.

Programmes and qualifications with the following main content are classified here:

Commercial law

Criminal justice studies

History of law

Indigenous law

Jurisprudence

Labour law

Legal practice

Notary/Notary's practise

Paralegal studies

\section{Exclusions}

Court reporting programmes and legal secretary programmes are excluded from this detailed field and included in detailed field 0415 "Secretarial and office work".

Police studies are excluded from this detailed field and included in detailed field 1032 'Protection of persons and property'.

048 Inter-disciplinary programmes and qualifications involving business, administration and law

\section{Inter-disciplinary programmes and qualifications involving business,} administration and law

Inter-disciplinary programmes and qualifications to which the greatest intended learning time is devoted to business, administration and law are classified here.

$\underline{\text { Inclusions }}$

Study of business and administration where emphasis is not given towards any of the detailed fields under 041 is included in this field.

\section{Exclusions}

Business programmes where emphasis is given to any of the detailed fields under 041 'Business and administration' (management, administration, marketing etc.) should be classified according to the specialisation. 


\title{
05 Natural Sciences, Mathematics and Statistics
}

\section{Biological and related sciences}

\section{Biology}

Biology is the study of the structure, function, reproduction, growth, evolution and behaviour of all living organisms.

Programmes and qualifications with the following main content are classified here:

\author{
Biology \\ Botany \\ Cell biology \\ Entomology \\ Genetics \\ Mycology \\ Zoology
}

\section{Exclusions}

Study of environmental sciences, which is the study of the relation between living organisms and the environment, is excluded from this detailed field and included in detailed field 0521 'Environmental sciences'. Study of chemical processes in living organisms (biochemistry, toxicology, pharmacology etc.) is excluded from this detailed field and included in detailed field 0512 'Biochemistry'.

\section{Biochemistry}

Biochemistry, sometimes called Biological chemistry, is the study of the chemistry of living organisms, including but not limited to, living matter.

Programmes and qualifications with the following main content are classified here:

Biological chemistry

Cell technology

Forensic sciences

Genetic code (DNA, RNA) studies

Genetic engineering

Pharmacology

Tissue culture technology

Toxicology

Virology

$\underline{\text { Inclusions }}$

Biotechnology is included here. 


\section{Environment}

\section{Environmental sciences}

Environmental sciences are the study of organisms in relation to one another and to the environment.

Programmes and qualifications with the following main content are classified here:

Ecology

Environmental science

\section{Exclusions}

The study of biology and toxicology are excluded from this detailed field and included under narrow field 051 'Biological and related sciences'.

\section{Natural environments and wildlife}

Natural environments and wildlife is the study of the relationships between living organisms in natural environments in order to protect nature and wildlife. It includes the study of establishing and maintaining national parks in order to preserve their original natural state.

Programmes and qualifications with the following main content are classified here:

National parks and wildlife management

Nature conservation

Wildlife

\section{Exclusions}

Study of agriculture, horticulture and forestry are excluded from this detailed field and included in some of the detailed fields under 08 'Agriculture, forestry, fisheries and veterinary'.

Study of hunting and trapping is excluded from this detailed field and included in detailed field 0821 'Forestry'.

\section{Physical sciences}

\section{Chemistry}

Chemistry is the study of substances and their elements and how they react when combined.

Programmes and qualifications with the following main content are classified here:

Inorganic chemistry

Organic chemistry

Physical chemistry

\section{Exclusions}

Biochemistry is excluded from this detailed field and included in detailed field 0512 'Biochemistry'. 


\section{Earth sciences}

Earth sciences is the study of the composition and structure of earth including the hydrosphere and the atmosphere.

Programmes and qualifications with the following main content are classified here:

Climate research

Earth science

Geodesy

Geography (physical)

Geology

Geomatics

Geospatial technology

Meteorology

Oceanography

Seismology

\section{Exclusions}

Social geography is excluded from this detailed field and included in detailed field 0314 'Sociology and cultural studies'. Soil science is excluded from this detailed field and included in detailed field 0811 'Crop and livestock production'.

\section{Physics}

Physics is the study of properties and interactions of matter and energy. It includes the study of astronomy and space science.

Programmes and qualifications with the following main content are classified here:

Astronomy

Astrophysics

Chemical physics

Medical physics

Optics

Physics

Space science

\section{Exclusions}

Opticians' practice is excluded from this detailed field and included in detailed field 0914 'Medical diagnostic and treatment technology'.

\section{Mathematics and statistics}

\section{Mathematics}

Mathematics is the study of abstract deductive systems. It includes algebra, arithmetic, geometry, real and complex analysis and pure and applied mathematics. 
Programmes and qualifications with the following main content are classified here:

Algebra

Geometry

Mathematics

Numerical analysis

Operational research

\section{Statistics}

Statistics is the study of collecting, describing, arranging and analysing numerical data. The study of probability theory and actuarial science is included.

Programmes and qualifications with the following main content are classified here:

Actuarial science

Probability theory

Statistics, applied

Survey design

Survey sampling

$\underline{\text { Inclusions }}$

Study of mathematical (theoretical) statistics is included here.

Exclusions

Demography/population studies is excluded from this detailed field and included in detailed field 0314 'Sociology and cultural studies'.

058 Inter-disciplinary programmes and qualifications involving natural sciences, mathematics and statistics

0588 Inter-disciplinary programmes and qualifications involving natural sciences, mathematics and statistics

Inter-disciplinary or broad programmes and qualifications to which the greatest intended learning time is devoted to natural sciences, mathematics and statistics are classified here. 


\section{Information and Communication Technologies}

\section{Information and Communication Technologies}

\section{Computer use}

Computer use is the study of using computers and computer software and applications for different purposes. These programmes are generally of short duration.

Programmes and qualifications with the following main content are classified here:

Computer use

Use of software for calculating (spread sheets)

Use of software for data processing

Use of software for desk top publishing

Use of software for word processing

Use of Internet

\section{Database and network design and administration}

Database and network design and administration is the study of the design, maintenance and integration of software applications. Computer media applications are included.

Programmes and qualifications with the following main content are classified here:

Computer administration and management

Computer media applications

Computer network installation and maintenance

Database administrator studies

Information technology administration

Information technology security

Network administration

Network design

Web design

\section{Software and applications development and analysis}

Software and applications development and analysis is the study of the design and development of computer systems and computing environments.

Programmes and qualifications with the following main content are classified here:

Computer programming

Computer science

Computer systems analysis

Computer systems design

Informatics

Operating systems

Programming languages development

Software development

Software programming 


\section{Exclusions}

Computer engineering (hardware) is excluded from this detailed field and included in detailed field 0714 'Electronics and automation'.

Programmes and qualifications in using computer applications are excluded from this detailed field and included in detailed field 0611 'Computer use'. Database and network design and administration is excluded from this detailed field and included in detailed field 0612 'Database and network design and administration'.

\section{Information and Communication Technologies not elsewhere classified}

Information technology studies not fitting in the detailed fields are classified here:

Artificial intelligence

068 Inter-disciplinary programmes and qualifications involving Information and Communication Technologies

0688 Inter-disciplinary programmes and qualifications involving Information and Communication Technologies

Inter-disciplinary programmes and qualifications to which the greatest intended learning time is devoted to information and communication technologies (ICTs) are classified here. 


\section{Engineering, Manufacturing and Construction}

\section{Engineering and engineering trades}

\section{Chemical engineering and processes}

Chemical engineering and processes is the study of planning, designing, and developing products and processes where chemical and physical changes occur. It includes designing chemical plants and control systems.

Programmes and qualifications with the following main content are classified here:

Chemical engineering

Chemical process engineering

Laboratory technology

Oil/gas/petrochemicals processing

Plant and machine operation (processing)

Process technology

$\underline{\text { Inclusions }}$

Laboratory technology is included here if emphasis is not given to a specific application.

\section{Exclusions}

Laboratory technology is excluded from this detailed field if emphasis is given to a specific application (biological, medical, etc.) and is included under the appropriate detailed field (0914 etc.). Biotechnology is excluded from this detailed field and included in detailed field 0512 'Biochemistry'.

Programmes and qualifications with emphasis on the production of a specific material are excluded from this detailed field (e.g. studies with emphasis on paper processing should be included in detailed field 0722 'Materials (glass, paper, plastic, wood)'.

\section{Environmental protection technology}

Environmental protection technology is the study of processes in order to minimise discharge and waste and avoid pollution. It includes programmes dealing with control of water, air, soil etc.

Programmes and qualifications with the following main content are classified here:

Air pollution control

Ecological technology

Energy efficiency

Environmental engineering

Industrial discharge control

Noise pollution control

Recycling

Water pollution control 


\section{Exclusions}

Programmes and qualifications dealing with hygienic standards in food, water etc. are excluded from this detailed field and included in detailed field 1021 'Community sanitation'.

Construction related to waste and water management is excluded from this detailed field and included in detailed field 0732 'Building and civil engineering'.

\section{Electricity and energy}

Electricity and energy is the study of installing, maintaining, repairing and diagnosing faults in electrical wiring and related equipment in domestic, commercial and industrial establishments. Installation and maintenance of overhead and underground electrical power distribution networks is included. Energy is the study of energy generation.

Programmes and qualifications with the following main content are classified here:

Air-conditioning trades

Climate engineering

Electrical appliances repairing

Electrical engineering

Electrical fitting

Electrical power generation

Electrical trades

Energy studies

Gas distribution

Heating trades

Nuclear, hydraulic and thermal energy

Power line installation and maintenance

Power production

Refrigeration

Solar power

Wind turbines

$\underline{\text { Inclusions }}$

The study of installing, diagnosing faults in and repairing heating, air-conditioning and refrigeration equipment is included here.

\section{Exclusions}

Study of vehicle electrical systems is excluded from this detailed field and included in detailed field 0716 'Motor vehicles, ships and aircraft'.

\section{Electronics and automation}

Electronics and automation is the study of planning, designing, developing maintaining and monitoring electronic equipment, machinery and systems. It includes designing computers and equipment for communication. 
Programmes and qualifications with the following main content are classified here:

Broadcasting electronics

Communication systems

Communications equipment installation

Communications equipment maintenance

Computer engineering

Computer repairing

Control engineering

Data processing technology

Digital technology

Electronic engineering

Electronic equipment servicing

Network technology

Robotics

Telecommunications technology

Television and radio repairing

\section{Exclusions}

Computer science (Software and applications development) is excluded from this detailed field and included under 0613 'Software and applications development and analysis'.

\section{Mechanics and metal trades}

Mechanics and metal trades is the study of planning, designing, developing, producing, maintaining and monitoring machines, mechanical plants and systems and metal products. It includes designing and maintaining machines which produce goods and services. The focus of study in this detailed field is machines, mechanical systems and metal products.

Programmes and qualifications with the following main content are classified here:

Gunsmithing

Hydraulics

Locksmithing and safe repairing

Mechanical engineering

Mechanical trades

Metal casting and patternmaking

Metal fitting, turning and machining

Metallurgical engineering

Precision mechanics

Sheet metal working

Steel production

Tool and die making

Welding

\section{Exclusions}

The study of motor vehicle mechanics and engineering is excluded from this detailed field and included in detailed field 0716 'Motor vehicles, ships and aircraft'. 


\section{Motor vehicles, ships and aircraft}

Motor vehicles, ships and aircraft is the study of designing, developing, producing, maintaining, diagnosing faults in, repairing and servicing motor vehicles, including earth moving equipment and agriculture machines, ships, trains and aircraft. Typical is the combination of studies in both metal structures and motors.

Programmes and qualifications with the following main content are classified here:

Aerospace engineering

Aircraft engineering

Aircraft maintenance

Automotive electrical systems

Automotive engineering

Avionics

Coachwork

Marine engineering

Motorcycle engineering

Panel beating

Shipbuilding

Train repair and maintenance

Vehicle building and repairing

Vehicle varnishing/spraying

$\underline{\text { Inclusions }}$

Study of vehicle electrical systems is included here.

\section{Exclusions}

Study of producing and repairing non-motorised vehicles is excluded from this detailed field and included in 0715 'Mechanics and metal work' (e.g. bicycles) or 0722 'Materials (glass, paper, plastic, wood)' (e.g. non-motor boats).

\section{Engineering and engineering trades not elsewhere classified}

Engineering studies not covered by other detailed fields are classified here:

Nanotechnology

\section{Manufacturing and processing}

\section{Food processing}

Food processing is the study of processing and packaging of food and beverages, and the equipment and procedures used in the production and distribution of foods. 
Programmes and qualifications with the following main content are classified here:

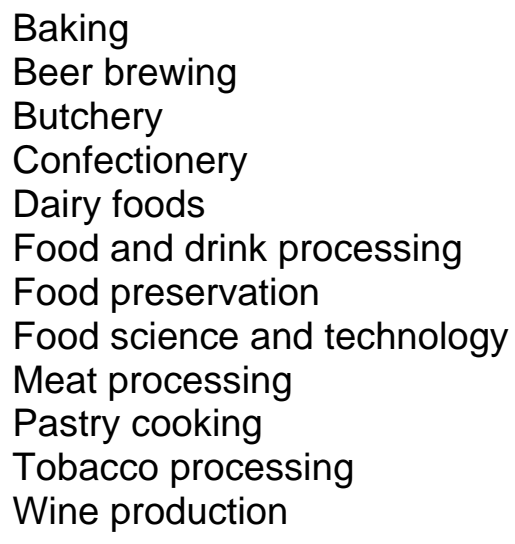

$\underline{\text { Inclusions }}$

Study of food handling and food hygiene is included here.

\section{Exclusions}

Restaurant and catering are excluded from this detailed field and included in detailed field 1013 'Hotel, restaurant and catering'.

Nutrition science is excluded from this detailed field and included in narrow field 051 'Biological and related sciences'.

\section{Materials (glass, paper, plastic and wood)}

Materials is the study of the manufacturing of products in glass, paper, plastic, wood or other materials like stone, clay, artificial materials etc. Programmes and qualifications included in this detailed field have more to do with a specific material than general technical knowledge.

Programmes and qualifications with the following main content are classified here:

Boat building (non-motor)

Cabinet making

Carpentry (furniture)

Ceramics (industrial)

Furniture making

Glass working (industrial)

Industrial diamond production

Paper manufacturing and processing

Plastic manufacturing

Rubber processing

Timber technology

Wood machining and turning

Woodwork trades 


\section{Exclusions}

Study of metal work is excluded from this detailed field and included in detailed field 0715 'Mechanics and metal trades'.

Study of building carpentry and joinery is excluded from this detailed field and included in detailed field 0732 'Building and civil engineering'.

Study of chemical processing in general is excluded from this detailed field and included in detailed field 0711 'Chemical engineering and processes'.

Study of printing and bookbinding is excluded from this detailed field and included in detailed field 0211 'Audio-visual techniques and media production'.

Handicrafts programmes (glass arts and crafts, woodcarving etc) are excluded from this detailed field and included in detailed field 0214 'Handicrafts'.

\section{Textiles (clothes, footwear and leather)}

Textiles (clothes, footwear and leather) is the study of the manufacture of textiles, textile and leather products, clothing and related items, shoes and other forms of footwear.

Programmes and qualifications with the following main content are classified here:

Clothing trades

Dressmaking

Footwear making

Fur making

Garment production

Leather processing

Saddlery

Shoemaking

Skins and leather production

Spinning

Tailoring

Textile trades

Upholstery

Weaving (industrial)

Wool science

\section{Exclusions}

Handicrafts studies (weaving, embroidery etc.) are excluded from this detailed field and included in detailed field 0214 'Handicrafts'.

\section{Mining and extraction}

Mining and extraction is the study of assessing, planning, developing, and directing the extraction of minerals, oil and gas from the earth. 
Programmes and qualifications with the following main content are classified here:

Coal mining

Mineral technology

Mining of minerals

Oil and gas drilling

Oil and gas extraction

Raw material extraction

\section{Exclusions}

Study of metallurgical engineering is excluded from this detailed field and included in 0715 'Mechanics and metal trades'

Study of geology is excluded from this detailed field and included in detailed field 0532 'Earth sciences'.

\section{Architecture and construction}

\section{Architecture and town planning}

Architecture is the study of the art, science and techniques of building design. It encompasses both utilitarian ends - such as the soundness of the structure and the functional and economic efficiency of the building - and aesthetic considerations. Town planning is the study of the regulated growth and improvement of towns in both functional and aesthetical points of view.

Programmes and qualifications with the following main content are classified here:

Architectural urban design and planning

Architecture

Building design

Cartography/Land surveying

City planning

Community development

Landscape architecture

Structural architecture

Surveying

Town and country planning

Urban planning

\section{Exclusions}

Study of interior design is excluded from this detailed field and included in detailed field 0212 'Fashion, interior and industrial design'. Geomatics is excluded from this detailed field and included in detailed field 0532 'Earth science'.

The laying out and construction of parks and gardens is excluded from this detailed field and included in detailed field 0812 'Horticulture'. 


\section{Building and civil engineering}

Building is the study of the science, technology and techniques of assembling, erecting and maintaining public, commercial, industrial and residential structures and their fittings. Civil engineering is the study of planning, designing, testing and directing the construction of large scale buildings and structures, including systems for transport, water supply, sewage etc.

Programmes and qualifications with the following main content are classified here:

Bricklaying

Bridge construction

Building construction

Building engineering

Building technology

Carpentry and joinery (building)

Civil engineering

Construction equipment

Constructional metalwork (building)

Dock and harbour engineering

Floor and wall tiling

Floor covering

House building

Industrial abseiling (commercial)

Masonry and tile setting

Painting and wall covering

Plastering

Plumbing and pipefitting

Road building

Water engineering and technology

Water supply and sewerage engineering

Ventilation

\section{$\underline{\text { Exclusions }}$}

Installation of electricity is excluded from this detailed field and included in detailed field 0713 'Electricity and energy'. Similarly, installing and repairing of heating, air-conditioning and refrigeration equipment is excluded from this detailed field and included in detailed field 0713 'Electricity and energy'.

\section{Inter-disciplinary programmes and qualifications involving engineering, manufacturing and construction}

\section{Inter-disciplinary programmes and qualifications involving engineering, manufacturing and construction}

Inter-disciplinary or broad programmes and qualifications to which the greatest intended learning time is devoted to engineering, manufacturing and construction are classified here. 


\section{Agriculture, Forestry, Fisheries and Veterinary}

\section{Agriculture}

\section{Crop and livestock production}

Crop and livestock production is the study of growing, maintaining and harvesting crops and pastures, and grazing and managing animals. It includes the study of managing and maintaining farms and producing unprocessed plant and animal products.

Programmes and qualifications with the following main content are classified here:

Agricultural sciences

Agronomy and crop science

Animal husbandry

Crop growing

Dog breeding

Farm and ranch management

Farming

Fruit growing

Grain growing

Horse breeding

Pig farming

Poultry husbandry

Rice farming

Rye and wheat growing

Sheep farming

Soil science

Sugar cane growing

Vegetable planting

Wine growing

$\underline{\text { Inclusions }}$

Study of soil fertility and irrigation techniques are included here.

Study of growing intensively managed crops such as fruit and vegetables is included here.

\section{Exclusions}

Study of wine production is excluded from this detailed field and is included in detailed field 0721 'Food processing'.

Jockeying is excluded from this detailed field and is included in detailed field 1014 'Sports'

\section{Horticulture}

Horticulture is the study of horticultural technology and management, floriculture, greenhouse methods, nursery management, landscape gardening etc. 
Programmes and qualifications with the following main content are classified here:

Floriculture

Gardening

Green keeping

Horticultural techniques

Nursery management

Turf cultivation

$\underline{\text { Inclusions }}$

The laying out and construction of urban and domestic parks and gardens is included here.

Gardening programmes combining floriculture and growing vegetables are included here.

\section{Exclusions}

Study of growing edible crops (such as wheat, rice, fruit, vegetables etc,) is excluded from this detailed field and included in detailed field 0811 'Crop and livestock production'.

Study of soil science, soil fertility and irrigation techniques is excluded from this detailed field and included in detailed field 0811 'Crop and livestock production'.

Study of National park management is excluded from this detailed field and included in detailed field 0522 'Natural environments and wildlife'.

Study of Landscape architecture is excluded from this detailed field and included in detailed field 0731 'Architecture and town planning'.

082 Forestry

\section{Forestry}

Forestry is the study of establishing, cultivating, harvesting and managing forests. It includes the study of hunting and trapping.

Programmes and qualifications with the following main content are classified here:

Charcoal burning

Forest keeping

Forest product techniques

Forestry

Hunting and trapping

Logging

Tree felling

\section{Exclusions}

Study of National park management is excluded from this detailed field and included in detailed field 0522 'Natural environments and wildlife'.

Timber technology (sawmill production etc) is excluded from this detailed field and included in detailed field 0722 'Materials (glass, paper, plastic and wood)'. 


\section{Fisheries}

\section{$0831 \quad$ Fisheries}

Fisheries is the study of breeding, rearing and harvesting fish and other seafood.

Programmes and qualifications with the following main content are classified here:

Aquaculture

Fish breeding

Fish farms

Fishery science and technology

Pearl cultivating

Seafood farming

Shellfish breeding

$\underline{\text { Inclusions }}$

Programmes for operating fishing boats are included here.

Exclusions

Study of industrial processing of fish is excluded from this detailed field and included in detailed field 0721 'Food processing'.

\section{Veterinary}

\section{Veterinary}

Veterinary is the study of preventing, diagnosing and treating diseases and injuries in animals, and their general care. The study of caring for sick, injured and infirm animals undergoing treatment in veterinary clinics is included. It also includes the study of providing assistance to veterinary scientists.

Programmes and qualifications with the following main content are classified here:

Animal health care

Animal reproduction (science)

Artificial insemination (of animals)

Veterinary assisting

Veterinary medicine

Veterinary nursing

Veterinary science

$\underline{\text { Inclusions }}$

The science of animal reproduction is included here.

\section{Exclusions}

Study of animal breeding is excluded from this detailed field and included in detailed field 0811 'Crop and livestock production'. 
088 Inter-disciplinary programmes and qualifications involving agriculture, forestry, fisheries and veterinary

0888 Inter-disciplinary programmes and qualifications involving agriculture, forestry, fisheries and veterinary

Inter-disciplinary or broad programmes and qualifications to which the greatest intended learning time is devoted to agriculture, forestry, fisheries and veterinary are classified here. 


\section{Health and Welfare}

\section{Health}

\section{Dental studies}

Dental studies are the study of diagnosing, treating and preventing diseases and abnormalities of the teeth and gums. It includes the study of designing, making and repairing dental prostheses and orthodontic appliances. It also includes the study of providing assistance to dentists.

Programmes and qualifications with the following main content are classified here:

Dental assisting

Dental hygiene

Dental laboratory technology

Dental nursing

Dental science

Dental surgery

Dental technology

Odontology

Oral surgery

Orthodontics

$\underline{\text { Inclusions }}$

Study of public dental health is included here.

\section{Medicine}

Medicine is the study of the principles and procedures used in preventing, diagnosing, caring for and treating illness, disease and injury in humans and the maintenance of general health. Principally, this detailed field consists of training of physicians/doctors.

Programmes and qualifications with the following main content are classified here:

Anaesthetics

Forensic medicine

Forensic pathology

General medicine

Gerontology

Gynaecology

Medical science

Medical training

Medicine

Paediatrics

Psychiatry

Surgery

Training of physicians/doctors 


\section{Nursing and midwifery}

Nursing is the study of providing health care for the sick, disabled or infirm and assisting physicians and other medical and health professionals diagnose and treat patients. The focus of qualifications in nursing is maintaining and caring for the health of patients during illness and rehabilitation. It includes health care of old people and health care of the disabled. Midwifery is the study of providing care to childbearing women during pregnancy, labour and birth and during the postpartum period. It also includes caring for the new born and assisting the mother with breast feeding.

Programmes and qualifications with the following main content are classified here:

Assistant nursing

Basic nursing

General nursing

Health care of old people

Heath care of the disabled

Health care programmes

Infant hygiene (nursing)

Midwifery

Nursing aide/Orderly

Psychiatric nursing

Specialised nursing

$\underline{\text { Inclusions }}$

Care programmes comprising both health care and social care e.g. for old people, are included here.

\section{Exclusions}

Veterinary nursing is excluded from this detailed field and is included in detailed field 0841 'Veterinary'.

Dental nursing is excluded from this detailed field and is included in detailed field 0911 'Dental studies'.

Non-medical care of children (not health care) is excluded from this detailed field and included in detailed field 0922 'Child care and youth services'.

Non-medical care of the elderly (not health care) is excluded from this detailed field and included in detailed field 0921 'Care of the elderly and disabled adults'. 


\section{Medical diagnostic and treatment technology}

Medical diagnostic and treatment technology is the study of a wide range of technologies used for diagnosing and treating diseases and handicaps.

Programmes and qualifications with the following main content are classified here:

Ambulance technology

Hearing aid technology

Medical laboratory technology

Optical technology

Prosthetic technology

Radiology technology

Radiotherapy

X-ray technology (medical)

\section{Exclusions}

Study of laboratory technology is excluded from this detailed field if emphasis is not given to medical laboratory technology. General laboratory technology is included in detailed field 0711 'Chemical engineering and processes'. Laboratory technology where emphasis is given to other specific applications (biology, chemistry, physics etc) is included in the appropriate detailed field (0511, 0531,0533 etc.).

Study of dental technology is excluded from this detailed field and included in detailed field 0911 'Dental studies'.

\section{Therapy and rehabilitation}

Therapy and rehabilitation is the study of restoring normal physical conditions to those incapacitated by temporary or permanent disability.

Programmes and qualifications with the following main content are classified here:

Dietician programmes

Medical massage

Nutrition/Dietetics

Occupational therapy

Physiotherapy

Rehabilitation

Speech therapy

\section{Exclusions}

Study of psychotherapy is excluded from this detailed field and included in detailed field 0313 'Psychology'.

Study of nutrition science is excluded from this detailed field and included in narrow field 051 'Biological and related sciences'. 


\section{Pharmacy}

Pharmacy is the study of drugs and their effects on humans. It includes their preparation, dispensing and administration.

Programmes and qualifications with the following main content are classified here:

Dispensing pharmacy

Pharmacy

\section{Exclusions}

Study of pharmacology is excluded from this detailed field and included in detailed field 0511 'Biology'.

\section{Traditional and complementary medicine and therapy}

Traditional and complementary medicine is the study of alternative medicine.

Programmes and qualifications with the following main content are classified here:

Acupuncture and oriental medicine

Aromatherapy

Ayurvedic medicine

Herbalism

Herbology

Holistic medicine

Homeopathic medicine

Traditional medicine, for example Chinese

\section{Welfare}

\section{Care of elderly and of disabled adults}

Care of the elderly and of disabled adults is the study of non-medical care of the elderly and disabled.

Programmes and qualifications with the following main content are classified here:

Care of the elderly

Non-medical care of disabled adults

Personal care of adults

\section{$\underline{\text { Exclusions }}$}

Study of health care of the elderly and disabled is excluded from this detailed field and included in detailed field 0913 'Nursing and midwifery'.

\section{Child care and youth services}

Child care and youth services are the study of the development and non-medical care of children and youths. It includes the study of recreation and leisure activities as a social service for school children and young adults. 
Programmes and qualifications with the following main content are classified here:

Child care

Child recreation programmes

Day care

Non-medical care of disabled children

Youth services

Youth worker programmes

\section{Exclusions}

Study of early childhood education in pre-schools is excluded from this detailed field and included in detailed field 0112 'Training for pre-school teachers'.

Study of health care of children is excluded from this detailed field and included in detailed field 0913 'Nursing and midwifery'.

\section{Social work and counselling}

Social work and counselling is the study of the welfare needs of communities, specific groups and individuals and the appropriate ways of meeting these needs. The focus is on social welfare with emphasis on social policy and practice.

Programmes and qualifications with the following main content are classified here:

Alcohol and drug abuse counselling

Alcohol, tobacco, drugs (knowledge about)

Crisis support

Family and marriage counselling

Mobbing and maltreatment (knowledge about)

Parole officer training

Probation officer training

Social policy

Social practice

Social theory (applied)

Social work (welfare)

Vocational counselling

Vocational guidance

\section{Exclusions}

Study of sociology and social science is excluded from this detailed field and included in detailed field 0314 'Sociology and cultural studies'.

Studies combining health care and social care (e.g. for old people) are excluded from this detailed field and included in detailed field 0913 'Nursing and midwifery'.

\section{Inter-disciplinary programmes and qualifications involving health and welfare}

\section{Inter-disciplinary programmes and qualifications involving health and welfare}

Inter-disciplinary or broad programmes and qualifications to which the greatest intended learning time is devoted to health and welfare are classified here. 


\section{Services}

\section{Personal services}

\section{Domestic services}

Domestic services are the study of various domestic services, such as housekeeping, cleaning, laundering, sewing etc.

Programmes and qualifications with the following main content are classified here:

Caretaking, housekeeping and home service workers

Chimney sweeping

Cleaning

Cooking (home)

Domestic science

Dry-cleaning

Funeral services and mortuary science

Home economics

Laundry

Needlework (home)

Sewing (home)

Window cleaning

$\underline{\text { Inclusions }}$

Cleaning is included here even if directed towards cleaning schools, hospitals, factories etc.

Exclusions

Study of building maintenance is excluded from this detailed field and included in detailed field 0732 'Building and civil engineering'.

\section{Hair and beauty services}

Hair and beauty services are the study of caring for the hair and the body for beautification.

Programmes and qualifications with the following main content are classified here:

Barbering

Beauty therapy

Cosmetology (make up)

Fitness and weight control

Hairdressing

Manicure

Pedicure

\section{Hotel, restaurants and catering}

Hotel, restaurants and catering is the study of providing food, beverages, accommodation and related services at hotels, restaurants etc. 
Programmes and qualifications with the following main content are classified here:

Catering

Cooking (restaurant and hotel-type)

Fast food preparation

Food serving

Hospitality services

Hotel and restaurant studies

Hotel receptionist training

Hotel services

Waiting and bar service

\section{Exclusions}

Study of food processing (industrial) is excluded from this detailed field and included in detailed field 0721 'Food processing'.

Receptionist training (general) is excluded from this detailed field and included in detailed field 0415 'Secretarial and office work'.

\section{Sports}

Sports is the study of techniques and skills in a chosen sport.

Programmes and qualifications with the following main content are classified here:

Sport trainer studies

Techniques and skills in a chosen sport

Training of umpires/referees and other sports officials

$\underline{\text { Inclusions }}$

Jockeying is included here. Chess playing is included here.

Exclusions

Training of school teachers in physical education (sports teachers) is excluded from this detailed field and included in detailed field 0114 'Teacher training with subject specialisation'.

Fitness services are excluded from this detailed field and included in detailed field 1012 'Hair and beauty services'. 


\section{Travel, tourism and leisure}

Travel and tourism is the study of marketing and advertising tourist destinations and events. It includes the study of ticketing and reservation practices. Leisure is the study of recreational and leisure activities for individuals and groups.

Programmes and qualifications with the following main content are classified here:

Abseiling (rope climbing)

Adventure based activities

Ground crew training (airport)

Guiding, tour leading

Recreation and leisure

Tourist trades programmes

Travel agency services

Travel and tourism

Travel services

$\underline{\text { Inclusions }}$

Basic training in how to treat tourists is included here.

\section{Exclusions}

Study of recreation and leisure activities for school children is excluded from this detailed field and included in detailed field 0922 'Child care and youth services'.

\section{Hygiene and occupational health services}

\section{Community sanitation}

Community sanitation is the study of community services dealing with items that affect public health such as hygienic standards in food, water supply, disposal of sewage and garbage and street cleaning.

Programmes and qualifications with the following main content are classified here:

Hygiene, community

Hygienic standards

Refuse collection

Refuse/sewage disposal

Street cleaning

Water supply (service)

Waste management 


\section{Occupational health and safety}

Occupational health and safety is the study of recognising, evaluating and controlling environmental factors associated with the workplace.

Programmes and qualifications with the following main content are classified here:

Ergonomics (occupational health and safety)

Health and safety in the workplace

Industrial welfare

Labour protection

Labour security

Labour welfare (safety)

Occupational health and industrial hygiene

Occupational safety

Stress management

Work environment

\section{Exclusions}

Study of vocational rehabilitation and occupational therapy is excluded from this detailed field and included in detailed field 0915 'Therapy and rehabilitation'.

Study of labour law is excluded from this detailed field and included in 0421 'Law'.

Study of ergonomics is excluded from this detailed field if emphasis is given to technical aspects and is included in the appropriate detailed field under 071 'Engineering and engineering trades'.

\section{Security services}

\section{Military and defence}

Military and defence is the study of services to the community connected with war and defence, designed to provide training in the principles and practice of military science.

Programmes and qualifications with the following main content are classified here:

Air force training

Army training

Defence studies

Military science

Navy training

War theory

\section{Exclusions}

Military personnel participating in non-military programmes should be classified according to the subject content of the training programme. 


\section{Protection of persons and property}

Protection of persons and property is the study of services to the community concerning protection of property and persons. It comprises training in police work, public security, fire protection and fire-fighting.

Programmes and qualifications with the following main content are classified here:

Civil security

Customs programmes

Fire-protection (fire-fighting)

Fire technology

Life guarding

Police work

Policing studies

Prison work

Public security

Security and loss prevention services

Security guarding

\section{Exclusions}

Study of law is excluded from this detailed field and included in 0421 'Law'.

Study of criminology is excluded from this detailed field and included in detailed field 0314 'Sociology and cultural studies'.

\section{Transport services}

\section{Transport services}

Transport is the study of operating, navigating and directing ships, train, aircraft and other forms of transportation.

Programmes and qualifications with the following main content are classified here:

Aircraft operation

Air traffic control

Air traffic safety

Cabin crew training

Communication (air, railway, road etc.) programmes

Crane and truck driving

Driving programmes

Flying and navigation

Navigation technologies

Postal service

Railway operations

Road motor vehicle operations

Ship operation

Shipping

Transport studies 


\section{Exclusions}

Programmes in telephone network services are excluded from this detailed field and included in detailed field 0714 'Electronics and automation'. Programmes in switchboard operating are excluded from this detailed field and included in detailed field 0415 'Secretarial and office work'.

108 Inter-disciplinary programmes and qualifications involving services

1088 Inter-disciplinary programmes and qualifications involving services

Inter-disciplinary programmes and qualifications to which the greatest intended learning time is devoted to services are classified here. 


\section{Appendix I}

\section{ISCED-F 2013: List of possible codes}

\begin{tabular}{|c|c|c|}
\hline Broad field & Narrow field & Detailed field \\
\hline \multirow[t]{5}{*}{$\begin{array}{l}00 \text { Generic programmes } \\
\text { and qualifications }\end{array}$} & $\begin{array}{l}000 \text { Generic programmes and } \\
\text { qualifications not further defined }\end{array}$ & $\begin{array}{l}0000 \text { Generic programmes and } \\
\text { qualifications not further defined }\end{array}$ \\
\hline & $\begin{array}{l}001 \text { Basic programmes and } \\
\text { qualifications }\end{array}$ & $\begin{array}{l}0011 \text { Basic programmes and } \\
\text { qualifications }\end{array}$ \\
\hline & 002 Literacy and numeracy & 0021 Literacy and numeracy \\
\hline & 003 Personal skills and development & 0031 Personal skills and development \\
\hline & $\begin{array}{l}009 \text { Generic programmes and } \\
\text { qualifications not elsewhere classified }\end{array}$ & $\begin{array}{l}0099 \text { Generic programmes and } \\
\text { qualifications not elsewhere classified }\end{array}$ \\
\hline \multirow[t]{2}{*}{01 Education } & 011 Education & $\begin{array}{l}0110 \text { Education not further defined } \\
0111 \text { Education science } \\
0112 \text { Training for pre-school teachers } \\
0113 \text { Teacher training without subject } \\
\text { specialisation } \\
0114 \text { Teacher training with subject } \\
\text { specialisation } \\
0119 \text { Education not elsewhere } \\
\text { classified }\end{array}$ \\
\hline & $\begin{array}{l}018 \text { Inter-disciplinary programmes } \\
\text { and qualifications involving education }\end{array}$ & $\begin{array}{l}0188 \text { Inter-disciplinary programmes and } \\
\text { qualifications involving education }\end{array}$ \\
\hline \multirow[t]{6}{*}{02 Arts and humanities } & $\begin{array}{l}020 \text { Arts and humanities not further } \\
\text { defined }\end{array}$ & $\begin{array}{l}0200 \text { Arts and humanities not further } \\
\text { defined }\end{array}$ \\
\hline & 021 Arts & $\begin{array}{l}\text { 0210 Arts not further defined } \\
0211 \text { Audio-visual techniques and } \\
\text { media production } \\
\text { 0212 Fashion, interior and industrial } \\
\text { design } \\
0213 \text { Fine arts } \\
0214 \text { Handicrafts } \\
0215 \text { Music and performing arts } \\
\text { 0219 Arts not elsewhere classified }\end{array}$ \\
\hline & 022 Humanities (except languages) & $\begin{array}{l}\text { 0220 Humanities (except languages) } \\
\text { not further defined } \\
0221 \text { Religion and theology } \\
0222 \text { History and archaeology } \\
0223 \text { Philosophy and ethics } \\
0229 \text { Humanities (except languages) } \\
\text { not elsewhere classified }\end{array}$ \\
\hline & 023 Languages & $\begin{array}{l}\text { 0230 Languages not further defined } \\
\text { 0231 Language acquisition } \\
\text { 0232 Literature and linguistics } \\
\text { 0239 Languages not elsewhere } \\
\text { classified }\end{array}$ \\
\hline & $\begin{array}{l}028 \text { Inter-disciplinary programmes } \\
\text { and qualifications involving arts and } \\
\text { humanities }\end{array}$ & $\begin{array}{l}0288 \text { Inter-disciplinary programmes and } \\
\text { qualifications involving arts and } \\
\text { humanities }\end{array}$ \\
\hline & $\begin{array}{l}029 \text { Arts and humanities not } \\
\text { elsewhere classified }\end{array}$ & $\begin{array}{l}0299 \text { Arts and humanities not } \\
\text { elsewhere classified }\end{array}$ \\
\hline
\end{tabular}




\begin{tabular}{|c|c|c|}
\hline Broad field & Narrow field & Detailed field \\
\hline \multirow{5}{*}{$\begin{array}{l}03 \text { Social sciences, } \\
\text { journalism and } \\
\text { information }\end{array}$} & $\begin{array}{l}\text { 030 Social sciences, journalism and } \\
\text { information not further defined }\end{array}$ & $\begin{array}{l}0300 \text { Social sciences, journalism and } \\
\text { information not further defined }\end{array}$ \\
\hline & 031 Social and behavioural sciences & $\begin{array}{l}\text { 0310 Social and behavioural sciences } \\
\text { not further defined } \\
0311 \text { Economics } \\
0312 \text { Political sciences and civics } \\
0313 \text { Psychology } \\
0314 \text { Sociology and cultural studies } \\
\text { 0319 Social and behavioural sciences } \\
\text { not elsewhere classified }\end{array}$ \\
\hline & 032 Journalism and information & $\begin{array}{l}\text { 0320 Journalism and information not } \\
\text { further defined } \\
0321 \text { Journalism and reporting } \\
0322 \text { Library, information and archival } \\
\text { studies } \\
0329 \text { Journalism and information not } \\
\text { elsewhere classified }\end{array}$ \\
\hline & $\begin{array}{l}038 \text { Inter-disciplinary programmes } \\
\text { and qualifications involving social } \\
\text { sciences, journalism and information }\end{array}$ & $\begin{array}{l}0388 \text { Inter-disciplinary programmes and } \\
\text { qualifications involving social sciences, } \\
\text { journalism and information }\end{array}$ \\
\hline & $\begin{array}{l}039 \text { Social sciences, journalism and } \\
\text { information not elsewhere classified }\end{array}$ & $\begin{array}{l}0399 \text { Social sciences, journalism and } \\
\text { information not elsewhere classified }\end{array}$ \\
\hline \multirow[t]{5}{*}{$\begin{array}{l}04 \text { Business, } \\
\text { administration and law }\end{array}$} & $\begin{array}{l}040 \text { Business, administration and law } \\
\text { not further defined }\end{array}$ & $\begin{array}{l}0400 \text { Business, administration and law } \\
\text { not further defined }\end{array}$ \\
\hline & 041 Business and administration & $\begin{array}{l}0410 \text { Business and administration not } \\
\text { further defined } \\
0411 \text { Accounting and taxation } \\
0412 \text { Finance, banking and insurance } \\
0413 \text { Management and administration } \\
0414 \text { Marketing and advertising } \\
0415 \text { Secretarial and office work } \\
0416 \text { Wholesale and retail sales } \\
0417 \text { Work skills } \\
0419 \text { Business and administration not } \\
\text { elsewhere classified }\end{array}$ \\
\hline & 042 Law & 0421 Law \\
\hline & $\begin{array}{l}048 \text { Inter-disciplinary programmes } \\
\text { and qualifications involving business, } \\
\text { administration and law }\end{array}$ & $\begin{array}{l}0488 \text { Inter-disciplinary programmes and } \\
\text { qualifications involving business, } \\
\text { administration and law }\end{array}$ \\
\hline & $\begin{array}{l}049 \text { Business, administration and law } \\
\text { not elsewhere classified }\end{array}$ & $\begin{array}{l}0499 \text { Business, administration and law } \\
\text { not elsewhere classified }\end{array}$ \\
\hline
\end{tabular}




\begin{tabular}{|c|c|c|}
\hline Broad field & Narrow field & Detailed field \\
\hline \multirow{7}{*}{$\begin{array}{l}05 \text { Natural sciences, } \\
\text { mathematics and } \\
\text { statistics }\end{array}$} & $\begin{array}{l}050 \text { Natural sciences, mathematics } \\
\text { and statistics not further defined }\end{array}$ & $\begin{array}{l}0500 \text { Natural sciences, mathematics } \\
\text { and statistics not further defined }\end{array}$ \\
\hline & 051 Biological and related sciences & $\begin{array}{l}0510 \text { Biological and related sciences } \\
\text { not further defined } \\
0511 \text { Biology } \\
0512 \text { Biochemistry } \\
\text { 0519 Biological and related sciences } \\
\text { not elsewhere classified }\end{array}$ \\
\hline & 052 Environment & $\begin{array}{l}0520 \text { Environment not further defined } \\
0521 \text { Environmental sciences } \\
0522 \text { Natural environments and wildlife } \\
0529 \text { Environment not elsewhere } \\
\text { classified }\end{array}$ \\
\hline & 053 Physical sciences & $\begin{array}{l}\text { 0530 Physical sciences not further } \\
\text { defined } \\
0531 \text { Chemistry } \\
0532 \text { Earth sciences } \\
0533 \text { Physics } \\
0539 \text { Physical sciences not elsewhere } \\
\text { classified }\end{array}$ \\
\hline & 054 Mathematics and statistics & $\begin{array}{l}0540 \text { Mathematics and statistics not } \\
\text { further defined } \\
0541 \text { Mathematics } \\
0542 \text { Statistics }\end{array}$ \\
\hline & $\begin{array}{l}058 \text { Inter-disciplinary programmes } \\
\text { and qualifications involving natural } \\
\text { sciences, mathematics and statistics }\end{array}$ & $\begin{array}{l}0588 \text { Inter-disciplinary programmes and } \\
\text { qualifications involving natural } \\
\text { sciences, mathematics and statistics }\end{array}$ \\
\hline & $\begin{array}{l}059 \text { Natural sciences, mathematics } \\
\text { and statistics not elsewhere classified }\end{array}$ & $\begin{array}{l}0599 \text { Natural sciences, mathematics } \\
\text { and statistics not elsewhere classified }\end{array}$ \\
\hline \multirow[t]{2}{*}{$\begin{array}{l}06 \text { Information and } \\
\text { Communication } \\
\text { Technologies (ICTs) }\end{array}$} & $\begin{array}{l}061 \text { Information and Communication } \\
\text { Technologies (ICTs) }\end{array}$ & $\begin{array}{l}\text { 0610 Information and Communication } \\
\text { Technologies (ICTs) not further defined } \\
0611 \text { Computer use } \\
0612 \text { Database and network design and } \\
\text { administration } \\
0613 \text { Software and applications } \\
\text { development and analysis } \\
0619 \text { Information and Communication } \\
\text { Technologies (ICTs) not elsewhere } \\
\text { classified }\end{array}$ \\
\hline & $\begin{array}{l}068 \text { Inter-disciplinary programmes } \\
\text { and qualifications involving } \\
\text { Information and Communication } \\
\text { Technologies (ICTs) }\end{array}$ & $\begin{array}{l}0688 \text { Inter-disciplinary programmes and } \\
\text { qualifications involving Information and } \\
\text { Communication Technologies (ICTs) }\end{array}$ \\
\hline
\end{tabular}




\begin{tabular}{|c|c|c|}
\hline Broad field & Narrow field & Detailed field \\
\hline \multirow{6}{*}{$\begin{array}{l}07 \text { Engineering, } \\
\text { manufacturing and } \\
\text { construction }\end{array}$} & $\begin{array}{l}070 \text { Engineering, manufacturing and } \\
\text { construction not further defined }\end{array}$ & $\begin{array}{l}0700 \text { Engineering, manufacturing and } \\
\text { construction not further defined }\end{array}$ \\
\hline & $\begin{array}{l}071 \text { Engineering and engineering } \\
\text { trades }\end{array}$ & $\begin{array}{l}0710 \text { Engineering and engineering } \\
\text { trades not further defined } \\
0711 \text { Chemical engineering and } \\
\text { processes } \\
0712 \text { Environmental protection } \\
\text { technology } \\
0713 \text { Electricity and energy } \\
0714 \text { Electronics and automation } \\
0715 \text { Mechanics and metal trades } \\
0716 \text { Motor vehicles, ships and aircraft } \\
0719 \text { Engineering and engineering } \\
\text { trades not elsewhere classified }\end{array}$ \\
\hline & 072 Manufacturing and processing & $\begin{array}{l}\text { 0720 Manufacturing and processing not } \\
\text { further defined } \\
0721 \text { Food processing } \\
0722 \text { Materials (glass, paper, plastic } \\
\text { and wood) } \\
0723 \text { Textiles (clothes, footwear and } \\
\text { leather) } \\
0724 \text { Mining and extraction } \\
0729 \text { Manufacturing and processing not } \\
\text { elsewhere classified }\end{array}$ \\
\hline & 073 Architecture and construction & $\begin{array}{l}\text { 0730 Architecture and construction not } \\
\text { further defined } \\
0731 \text { Architecture and town planning } \\
0732 \text { Building and civil engineering }\end{array}$ \\
\hline & $\begin{array}{l}078 \text { Inter-disciplinary programmes } \\
\text { and qualifications involving } \\
\text { engineering, manufacturing and } \\
\text { construction }\end{array}$ & $\begin{array}{l}0788 \text { Inter-disciplinary programmes and } \\
\text { qualifications involving engineering, } \\
\text { manufacturing and construction }\end{array}$ \\
\hline & $\begin{array}{l}079 \text { Engineering, manufacturing and } \\
\text { construction not elsewhere classified }\end{array}$ & $\begin{array}{l}0799 \text { Engineering, manufacturing and } \\
\text { construction not elsewhere classified }\end{array}$ \\
\hline \multirow[t]{7}{*}{$\begin{array}{l}08 \text { Agriculture, forestry, } \\
\text { fisheries and veterinary }\end{array}$} & $\begin{array}{l}080 \text { Agriculture, forestry, fisheries and } \\
\text { veterinary not further defined }\end{array}$ & $\begin{array}{l}0800 \text { Agriculture, forestry, fisheries and } \\
\text { veterinary not further defined }\end{array}$ \\
\hline & 081 Agriculture & $\begin{array}{l}0810 \text { Agriculture not further defined } \\
0811 \text { Crop and livestock production } \\
0812 \text { Horticulture } \\
0819 \text { Agriculture not elsewhere } \\
\text { classified }\end{array}$ \\
\hline & 082 Forestry & 0821 Forestry \\
\hline & 083 Fisheries & 0831 Fisheries \\
\hline & 084 Veterinary & 0841 Veterinary \\
\hline & $\begin{array}{l}088 \text { Inter-disciplinary programmes } \\
\text { and qualifications involving } \\
\text { agriculture, forestry, fisheries and } \\
\text { veterinary }\end{array}$ & $\begin{array}{l}0888 \text { Inter-disciplinary programmes and } \\
\text { qualifications involving agriculture, } \\
\text { forestry, fisheries and veterinary }\end{array}$ \\
\hline & $\begin{array}{l}089 \text { Agriculture, forestry, fisheries and } \\
\text { veterinary not elsewhere classified }\end{array}$ & $\begin{array}{l}0899 \text { Agriculture, forestry, fisheries and } \\
\text { veterinary not elsewhere classified }\end{array}$ \\
\hline
\end{tabular}




\begin{tabular}{|c|c|c|}
\hline Broad field & Narrow field & Detailed field \\
\hline \multirow[t]{5}{*}{09 Health and welfare } & $\begin{array}{l}\text { 090 Health and welfare not further } \\
\text { defined }\end{array}$ & $\begin{array}{l}0900 \text { Health and welfare not further } \\
\text { defined }\end{array}$ \\
\hline & 091 Health & $\begin{array}{l}0910 \text { Health not further defined } \\
0911 \text { Dental studies } \\
0912 \text { Medicine } \\
0913 \text { Nursing and midwifery } \\
0914 \text { Medical diagnostic and treatment } \\
\text { technology } \\
0915 \text { Therapy and rehabilitation } \\
0916 \text { Pharmacy } \\
0917 \text { Traditional and complementary } \\
\text { medicine and therapy } \\
0919 \text { Health not elsewhere classified }\end{array}$ \\
\hline & 092 Welfare & $\begin{array}{l}0920 \text { Welfare not further defined } \\
0921 \text { Care of the elderly and of } \\
\text { disabled adults } \\
0922 \text { Child care and youth services } \\
0923 \text { Social work and counselling } \\
0929 \text { Welfare not elsewhere classified }\end{array}$ \\
\hline & $\begin{array}{l}098 \text { Inter-disciplinary programmes } \\
\text { and qualifications involving health and } \\
\text { welfare }\end{array}$ & $\begin{array}{l}0988 \text { Inter-disciplinary programmes and } \\
\text { qualifications involving health and } \\
\text { welfare }\end{array}$ \\
\hline & $\begin{array}{l}099 \text { Health and welfare not elsewhere } \\
\text { classified }\end{array}$ & $\begin{array}{l}0999 \text { Health and welfare not elsewhere } \\
\text { classified }\end{array}$ \\
\hline \multirow[t]{7}{*}{10 Services } & 100 Services not further defined & 1000 Services not further defined \\
\hline & 101 Personal services & $\begin{array}{l}\text { 1010 Personal services not further } \\
\text { defined } \\
1011 \text { Domestic services } \\
1012 \text { Hair and beauty services } \\
1013 \text { Hotel, restaurants and catering } \\
1014 \text { Sports } \\
1015 \text { Travel, tourism and leisure } \\
1019 \text { Personal services not elsewhere } \\
\text { classified }\end{array}$ \\
\hline & $\begin{array}{l}102 \text { Hygiene and occupational health } \\
\text { services }\end{array}$ & $\begin{array}{l}1020 \text { Hygiene and occupational health } \\
\text { services not further defined } \\
1021 \text { Community sanitation } \\
1022 \text { Occupational health and safety } \\
1029 \text { Hygiene and occupational health } \\
\text { services not elsewhere classified }\end{array}$ \\
\hline & 103 Security services & $\begin{array}{l}1030 \text { Security services not further } \\
\text { defined } \\
1031 \text { Military and defence } \\
1032 \text { Protection of persons and } \\
\text { property } \\
1039 \text { Security services not elsewhere } \\
\text { classified }\end{array}$ \\
\hline & 104 Transport services & 1041 Transport services \\
\hline & $\begin{array}{l}108 \text { Inter-disciplinary programmes } \\
\text { and qualifications involving services }\end{array}$ & $\begin{array}{l}1088 \text { Inter-disciplinary programmes and } \\
\text { qualifications involving services }\end{array}$ \\
\hline & 109 Services not elsewhere classified & 1099 Services not elsewhere classified \\
\hline 99 Field unknown & 999 Field unknown & 9999 Field unknown \\
\hline
\end{tabular}




\section{Appendix II}

\section{Numerical code list}

00 Generic programmes and qualifications

000 Generic programmes and qualifications not further defined

0000 Generic programmes and qualifications not further defined

001 Basic programmes and qualifications

0011 Basic programmes and qualifications

Basic programmes and qualifications

Broad generic (non-specialised) programmes and qualifications

General programmes and qualifications with no specific subject emphasis

Programmes and qualifications at primary level

002 Literacy and numeracy

0021 Literacy and numeracy

Basic remedial programmes for youth or adults

Functional literacy

Literacy

Numeracy

Simple literacy

003 Personal skills and development

0031 Personal skills and development

Argumentation and presentation

Assertiveness training

Communication skills

Co-operation

Development of behavioural capacities
Development of mental skills

Development of personal organisational capacities

Enhancing personal skills

Family life development training

Job-seeking programmes

Life orientation programmes

Parenting courses

Personal career planning

Personal development

Positive thinking

Presentation techniques

Public speaking

Self-confidence

Self-esteem skills

Social competence

Teamwork

Time management

009 Generic programmes and qualifications not elsewhere classified

0099 Generic programmes and qualifications not elsewhere classified

01 Education

011 Education

0110 Education not further defined

0111 Education science

Curriculum development (theory)

Curriculum studies

Didactics 
Distance education methodology

Education science

Educational assessment, testing and measurement

Educational evaluation and research

Paedagogical sciences (education)

0112 Training for pre-school teachers

Early childhood teaching (within formal school settings)

Pre-primary teacher training

0113 Teacher training without subject specialisation training

Adult literacy and numeracy teacher

Class teacher training

Elementary teacher education

Indigenous teacher training

Lower secondary teaching

Primary teaching

Special education teaching

0114 Teacher training with subject specialisation

Teacher training - arts and crafts

Teacher training - commercial subjects

Teacher training - music

Teacher training - nursing

Teacher training - physical training

Teacher training - second languages

Teacher training - specific theoretical subjects (e.g. mathematics, history)

Teacher training - technical subjects

Teacher training - vocational subjects

Teacher training courses for university teachers

Training of driving instructors

0119 Education not elsewhere classified
018 Inter-disciplinary programmes and qualifications involving education

0188 Inter-disciplinary programmes and qualifications involving education

02 Arts and humanities

020 Arts and humanities not further defined

0200 Arts and humanities not further defined

021 Arts

0210 Arts not further defined

0211 Audio-visual techniques and media production

Animation

Binding and finishing (printing)

Bookbinding

Camera operating

Cinematography

Compositing (printing)

Composition equipment operating

Computer game production

Computer graphics

Computer type-setting

Desktop publishing

Disc jockey training

Film and TV editing

Film and video production

Graphic design

Graphic reproduction

Illustration

Interactive media design

Lay-out

Media techniques

Multimedia production

Photo developing

Photography 
Pre-press operations

Print finishing and binding

Printing

Printing machining

Publishing design

Radio and TV production

Recorded music production

Sound and vision

Sound techniques

Type-setting

\section{Fashion, interior and industrial design}

Costume design

Design

Design of industrial products (artistic)

Fashion design

Industrial design (artistic)

Interior architecture

Interior decorating

Interior design

Stage designing

Three dimensional design

Window dressing

\section{Fine arts}

Aesthetics

Art history

Art studies

Art theory

Calligraphy

Drawing (artistic)

Etching (artistic)

Fine art printmaking

History of art

Lithography

Painting (art)
Philosophy of art

Sculpture

Sketching (art)

\section{Handicrafts}

Ceramics (craft)

Conservation of cultural material

Craft programmes

Crafts, folk arts and artisan

Decorative metal crafts

Embroidery (craft)

Fibre, textile and weaving arts

Floristry (flower arranging)

Glass arts and craft

Goldsmithing

Handicrafts

Indigenous crafts

Jewellery design

Jewellery making (craft)

Lapidary and jewellery

Making of musical instruments (not industrial)

Musical instruments (repairing and tuning)

Needle craft

Picture framing

Silversmithing

Stone carving (craft)

Weaving (craft)

Woodcarving

\section{Music and performing arts}

Acting and directing

Ballet

Choreography

Circus

Composition (music) 
Conducting (music)

Creative and performance art

Dance

Directing (theatre)

Drama

Elocution

Fashion modelling

History of film and theatre

History of music

Music

Music and the stage

Music composition

Music conducting

Musicology

Performing arts

Theatre/theatre sciences

0219 Arts not elsewhere classified

022 Humanities (excluding languages)

0220 Humanities (excluding languages) not further defined

0221 Religion and theology

Religion

Religious history

Religious studies

Study of different religions

Study of sacred books

Theology

0222 History and archaeology

Archaeology

Cultural history

Folklore studies

History

History and philosophy of science and technology

History of literature
History of medicine

History of science and ideas

History of technology

Literature history

Medieval and renaissance studies

Preservation of artistic heritage

0223 Philosophy and ethics

Ethics

Logic

Morals

Philosophy

0229 Humanities (except languages) not elsewhere classified

023 Languages

0230 Languages not further defined

0231 Language acquisition

Classical languages

Exogenous languages

Foreign languages

Interpretation programmes

Phonetics

Second languages

Semantics, foreign languages

Sign language interpreting

Sign languages

Translation programmes

0232 Literature and linguistics

Comparative literature

Creative writing

First language programmes

Indigenous languages

Linguistics, general

Literature

Mother tongue programmes

Native first languages 
Philology (first language)

Semantics (first language)

Speech and rhetorical studies

0239 Languages not elsewhere classified

028 Inter-disciplinary programmes and qualifications involving arts and humanities

0288 Inter-disciplinary programmes and qualifications involving arts and humanities

029 Arts and humanities not elsewhere classified

0299 Arts and humanities not elsewhere classified

03 Social sciences, journalism and information

030 Social sciences, journalism and information not further defined

0300 Social sciences, journalism and information not further defined

031 Social and behavioural sciences

0310 Social and behavioural sciences not further defined

0311 Economics

Econometrics

Economic history

Economics

International economics

Macro economics

National accounts

Political economics

0312 Political sciences and civics

Civics

Human rights

International relations

Peace and conflict studies

Political history

Political science
Politics

Public policy studies

0313 Psychology

Cognitive sciences

Conversational therapy

Development and child psychology

Psychoanalysis

Psychology

Psychotherapy

0314 Sociology and cultural studies

Criminology

Cultural geography

Cultural studies

Demography/population studies

Ethnology

Futurology

Gender studies

Geography (social)

Human geography

Regional cultures

Social anthropology

Social conflict theory

Social geography

Sociology

Women's studies

0319 Social and behavioural sciences not elsewhere classified

032 Journalism and information

0320 Journalism and information not further defined

0321 Journalism and reporting

Broadcast journalism

Editing

Information (wording and content)

Journalism 
Mass communication (wording and content)

News reporting

Publishing (dissemination of messages)

0322 Library, information and archival studies

Archival sciences

Curatorial studies

Documentation

Information science

Information searching

Librarianship training

Library studies

Museum documentation

Museum studies

Museology

0329 Journalism and information not elsewhere classified

038 Inter-disciplinary programmes and qualifications involving social sciences, journalism and information

0388 Inter-disciplinary programmes and qualifications involving social sciences, journalism and information

039 Social sciences, journalism and information not elsewhere classified

0399 Social sciences, journalism and information not elsewhere classified

04 Business, administration and law

040 Business, administration and law not further defined

0400 Business, administration and law not further defined

041 Business and administration

0410 Business and administration not further defined

0411 Accounting and taxation
Accounting

Auditing

Bookkeeping

Tax accounting

Tax management

0412 Finance, banking and insurance

Bank teller studies

Banking and finance

Business finance

Finance, banking, insurance

Finance theory

Financial management

Insurance

Investment analysis

Investments and securities

Pension insurance

Social insurance

Stock-broking

0413 Management and administration

Administration

Business administration

Educational management

Employment management

Entrepreneurship

Enterprise training

Health administration

Human resources management

Local public administration

Logistic management

Management of education

Management science

Management skills

Office management

Organisational theory and behaviour

Performance appraisal 
Personnel administration

Personnel management

Public administration

Public and institution management

Quality management

Recruitment

'Start your own business' courses

Supply change management

Training management

\section{Marketing and advertising}

Advertising

Consumer behaviour

Market research

Marketing

Merchandising

Public relations

Sales and marketing

\section{Secretarial and office work}

Administrative and secretarial services

Business correspondence

Clerical programmes

Court reporting

Data entry

Foreign language secretary programmes

Information processing/data entry

Keyboard skills

Legal secretary programmes

Management support services

Medical secretary programmes

Office automation

Operation of office equipment

Receptionist training

Secretarial programmes

Shorthand
Stenography

Switchboard operating

Typing

\section{Wholesale and retail sales}

Auctioneering

Buying and selling

Consumer services

Dairy retailing

Demonstration techniques

Property sales

Purchasing

Purchasing, procurement and contracts

Real-estate business

Retailing

Sales representatives

Stock-keeping

Telephone selling

Ware-housing

Wholesaling

\section{Work skills}

Clients' needs

Company knowledge

Customer service training

Industrial relations

Introduction to work courses

Organisation at work

Quality assurance

Trade union courses (general)

Work development

Work place skills

Working life

0419 Business and administration not elsewhere classified

042 Law

0421 Law 
Commercial law

Criminal justice studies

History of law

Indigenous law

Islamic sharia

Jurisprudence

Labour law

Law

Legal practice

Legal studies

Notary/Notary's practise

Paralegal studies

048 Inter-disciplinary programmes and qualifications involving business, administration and law

0488 Inter-disciplinary programmes and qualifications involving business, administration and law

049 Business, administration and law not elsewhere classified

0499 Business, administration and law not elsewhere classified

05 Natural sciences, mathematics and statistics

050 Natural sciences, mathematics and statistics not further defined

0500 Natural sciences, mathematics and statistics not further defined

051 Biological and related sciences

0510 Biological and related sciences not further defined

\section{Biology}

Biology

Biometrics

Botany

Cell biology

Entomology

Genetics
Life sciences

Limnology

Microbiology

Molecular biology

Mycology

Ornithology

Parasitology

Zoology

0512 Biochemistry

Biological chemistry

Biotechnology

Cell technology

Forensic sciences

Genetic code (DNA, RNA) studies

Genetic engineering

Pharmacology

Tissue culture technology

Toxicology

Virology

0519 Biological and related sciences not elsewhere classified

052 Environment

0520 Environment not further defined

0521 Environmental sciences

Ecology

Environmental science

0522 Natural environments and wildlife

Conservation and land management

National parks and wildlife

management

Nature conservation

Wildlife management

Wildlife ranger studies

0529 Environment not elsewhere classified

053 Physical sciences 
0530 Physical sciences not further defined

\section{Chemistry}

Analytical chemistry

Chemistry

Inorganic chemistry

Organic chemistry

Petrology

Physical chemistry

Polymer chemistry

\section{Earth sciences}

Atmospheric sciences

Climate research

Earth science

Geodesy

Geographic information systems (GIS)

Geography (nature)

Geography (physical)

Geoinformatics

Geology

Geomatics

Geophysics

Geoscience

Geospatial technology

Hydrogeology

Hydrology

Marine science

Meteorology

Mineralogy

Ocean life sciences

Oceanography

Palaeontology

Seismology

Vulcanology

\section{Physics}

Acoustics

Astronomy

Astrophysics

Biophysics

Chemical physics

Medical physics

Nuclear physics

Optics

Physics

Planetary sciences

Space science

0539 Physical sciences not elsewhere classified

\section{Mathematics and statistics}

0540 Mathematics and statistics not further defined

\section{Mathematics}

Algebra

Applied mathematics

Data analysis (mathematics)

Geometry

Mathematics

Numerical analysis

Operational research

Pure mathematics

\section{Statistics}

Actuarial science

Applied statistics

Mathematical (theoretical) statistics

Probability theory

Survey design

Survey sampling 
058 Inter-disciplinary programmes and qualifications involving natural sciences, mathematics and statistics

0588 Inter-disciplinary programmes and qualifications involving natural sciences, mathematics and statistics

059 Natural sciences, mathematics and statistics not elsewhere classified

0599 Natural sciences, mathematics and statistics not elsewhere classified

06 Information and Communication Technologies (ICTs)

061 Information and Communication Technologies (ICTs)

0610 Information and Communication Technologies (ICTs) not further defined

0611 Computer use

Computer software use

Computer use

Internet use

Use of software for calculating (spreadsheets)

Use of software for data processing Use of software for desktop publishing Use of software for word processing

0612 Database and network design and administration

Computer administration and management

Computer media applications

Computer network installation and maintenance

Computer support

Database administrator studies Information technology administration Information technology security

Network administration

Network design
Web design

0613 Software and applications development and analysis

Computer programming

Computer science

Computer systems analysis

Computer systems design

Informatics (computer science)

Operating systems

Programming (computer)

Programming languages development

Software development

Software localisation

Software programming

Software testing

0619 Information and Communication Technologies (ICTs) not elsewhere classified

Artificial intelligence

068 Inter-disciplinary programmes and qualifications involving Information and Communication Technologies (ICTs)

0688 Inter-disciplinary programmes and qualifications involving Information and Communication Technologies (ICTs)

07 Engineering, manufacturing and construction

070 Engineering, manufacturing and construction not further defined

0700 Engineering, manufacturing and construction not further defined

071 Engineering and engineering trades

0710 Engineering and engineering trades not further defined

0711 Chemical engineering and processes

Chemical engineering

Chemical process engineering 
Laboratory assistant programmes

Laboratory technician programmes

Laboratory technology

Oil/gas/petrochemicals processing

Oil refining

Plant and machine operation

(processing)

Process technology

\section{Environmental protection technology}

Air pollution control

Ecological technology

Energy efficiency

Environmental control

Environmental engineering

Environmental protection technology

Industrial discharge control

Noise pollution control

Recycling

Water pollution control

\section{Electricity and energy}

Air-conditioning trades (installation and maintenance)

Climate engineering

Electrical appliances repairing

Electrical engineering

Electrical fitting

Electrical power generation

Electrical trades

Energy studies

Gas distribution

Heating trades (installation and maintenance)

Nuclear, hydraulic and thermal energy

Power line installation and maintenance

Power production

Refrigeration
Solar energy

Solar power

Wind turbines

\section{Electronics and automation}

Automation

Broadcasting electronics

Communication systems

Communications equipment installation

Communications equipment

maintenance

Computer engineering

Computer repairing

Control engineering

Data processing technology

Digital technology

Electronic engineering

Electronic equipment servicing

Network technology

Robotics

Telecommunications technology

Television and radio repairing

\section{Mechanics and metal trades}

Bicycle production

Bicycle repair

Boilermaking and welding

Gunsmithing

Hydraulics

Locksmithing and safe repairing

Mechanical engineering

Mechanical trades

Metal casting and patternmaking

Metal fitting, turning and machining

Metal trades programmes

Metallurgical engineering

Metallurgical technology 
Micromechanics

Precision mechanics

Sheet metal working

Steel production

Tool and die making

Watchmaking

Welding

0716 Motor vehicles, ships and aircraft

Aeronautical engineering

Aerospace engineering

Agriculture machinery mechanics

Aircraft engineering

Aircraft maintenance

Automotive electrical systems

Automotive engineering

Avionics

Coachwork

Helicopter construction

Marine construction

Marine engineering

Maritime engineering

Motorcycle engineering

Motorcycle mechanics

Naval engineering

Panel beating

Shipbuilding

Train repair and maintenance

Vehicle and motor engineering

Vehicle building

Vehicle diagnostics

Vehicle electrical systems

Vehicle mechanics

Vehicle painting

Vehicle repairing

Vehicle trimming
Vehicle varnishers/sprayers

0719 Engineering and engineering trades not elsewhere classified

Nanotechnology

072 Manufacturing and processing

0720 Manufacturing and processing not further defined

0721 Food processing

Baking

Brewing

Butchery

Cheese production

Confectionery

Dairy foods (industrial)

Dairy science

Distilling

Food and drink processing

Food handling/hygiene

Food preparation

Food preservation

Food processing industry

Food science

Food science and technology

Food techniques

Industrial bakery/flour production

Meat processing

Pastry cooking

Tobacco processing

Wine production

Wine science

Wine storing/maturing

0722 Materials (glass, paper, plastic and wood)

Boat building (non-motor)

Cabinet making

Cane, willow and bamboo work 
Carpentry (furniture)

Ceramics (industrial)

Furniture crafts

Furniture making

Glass production

Glass working (industrial)

Industrial diamond production

Paper manufacturing and processing

Plastic manufacturing

Rubber processing

Stone cutting

Synthetic fibre manufacturing

Timber technology

Wood machining and turning

Wood technology

Woodwork trades

Woodworking and carpentry

0723 Textiles (clothes, footwear and leather)

Clothing, apparel and textile working

Clothing industry

Clothing trades

Custom tailoring

Cutting and tailoring

Dressmaking

Embroidery and needlework (industrial)

Footwear making

Fur making

Furrier

Garment production

Knitting (industrial)

Leather goods production

Leather processing

Leather trades

Pelt worker
Saddlery

Sewing (industrial)

Shoe, boot and leather repairing

Shoemaking

Skins and leather production

Soft furnishings

Spinning

Tailoring

Textiles, clothing and footwear

Textile techniques

Textile trades

Upholstery

Weaving (industrial)

Wool science

\section{Mining and extraction}

Coal mining

Drilling

Mineral technology

Mining engineering

Mining of minerals

Mining technology

Oil and gas drilling

Oil and gas extraction

Quarry supervision

Raw material extraction

0729 Manufacturing and processing not elsewhere classified

\section{Architecture and construction}

0730 Architecture and construction not further defined

\section{Architecture and town planning}

Architectural urban design and planning

Architecture

Building design 
Cartography/Land surveying

City planning

Community development

Community planning

Landscape architecture

Rural development

Structural architecture

Surveying

Topography

Town and country planning

Town and regional planning

Town planning

Urban planning

Urban studies

\section{Building and civil engineering}

Bricklaying

Brickwork and masonry

Bridge construction

Building construction

Building engineering

Building maintenance

Building renovation

Building technology

Carpentry and joinery (building)

Cement working

Civil engineering

Construction equipment

Construction plant operation

Construction technology

Constructional engineering

Constructional metalwork (building)

Demolition

Dock and harbour engineering

Drawing, technical

Excavation engineering
Floor and wall tiling

Floor covering

Glazing

House building

Industrial abseiling (commercial)

Insulation

Irrigation and drainage (construction)

Joinery and carpentry (building)

Masonry and tile setting

Painting and wall covering

Pipe fitting

Plastering (building)

Plumbing

Quantity surveying

Road building

Roof fixing

Sanitation (building)

Scaffolding work

Stonemasonry

Structural engineering

Technical drawing

Water supply and sewerage engineering

Water technology and engineering

Ventilation (building)

078 Inter-disciplinary programmes and qualifications involving engineering, manufacturing and construction

0788 Inter-disciplinary programmes and qualifications involving engineering, manufacturing and construction

079 Engineering, manufacturing and construction not elsewhere classified

0799 Engineering, manufacturing and construction not elsewhere classified 
08 Agriculture, forestry, fisheries and veterinary

080 Agriculture, forestry, fisheries and veterinary not further defined

0800 Agriculture, forestry, fisheries and veterinary not further defined

081 Agriculture

0810 Agriculture not further defined

0811 Crop and livestock production

Agricultural business/agribusiness operations

Agricultural economics

Agricultural sciences

Agriculture

Agronomy and crop science

Animal breeding

Animal husbandry

Animal training

Basic skills in agriculture

Crop growing

Dog breeding

Farm and ranch management

Farm maintenance

Farming

Fruit growing

Fruit production

Goose keeping

Grain growing

Horse breeding

Horse husbandry

Irrigation techniques

Olive growing

Orchards construction

Pig farming

Poultry husbandry

Race horse care
Rye and wheat growing

Sheep farming

Soil and water technician programmes

Soil fertility

Soil science

Sugar cane growing

Vegetable plantation

Wine growing

Vineyard construction

Viticulture

0812 Horticulture

Floriculture

Gardening

Green keeping

Greenhouse operations

Horticultural techniques

Horticulture

Landscape gardening

Nursery management (horticulture)

Ornamental plants production

Sports grounds maintenance

Turf cultivation and management

0819 Agriculture not elsewhere classified

082 Forestry

0821 Forestry

Charcoal burning

Forest keeping

Forest product techniques

Forest ranging

Forestry

Hunting and trapping

Logging

Tree felling 
083 Fisheries

0831 Fisheries

Aquaculture

Deep sea fishing

Fish breeding

Fish farms

Fish husbandry

Fishery

Fishery science and technology

Mariculture

Pearl cultivating

Sea food breeding

Shellfish breeding

084 Veterinary

0841 Veterinary

Animal health care

Animal reproduction (science)

Artificial insemination (of animals)

Veterinary assisting

Veterinary medicine

Veterinary nursing

Veterinary science

088 Inter-disciplinary programmes and qualifications involving agriculture, forestry, fisheries and veterinary

0888 Inter-disciplinary programmes and qualifications involving agriculture, forestry, fisheries and veterinary

089 Agriculture, forestry, fisheries and veterinary not elsewhere classified

0899 Agriculture, forestry, fisheries and veterinary not elsewhere classified

09 Health and welfare

090 Health and welfare not further defined

0900 Health and welfare not further defined

\section{Health}

0910 Health not further defined

0911 Dental studies

Clinical dentistry

Dental assisting

Dental hygiene

Dental laboratory technology

Dental nursing

Dental science

Dental surgery

Dental technology

Dentistry

Odontology

Oral surgery

Orthodontics

0912 Medicine

Anaesthetics

Anatomy

Audiology/hearing sciences

Bacteriology

Cardiology

Cytology

Dermatology

Epidemiology

Forensic medicine

Forensic pathology

General medicine

Gerontology

Gynaecology

Haematology

Histology

Immunology

Internal medicine

Medical science

Medical training 
Medicine

Naturopathic medicine

Neurology

Obstetrics and gynaecology

Oncology

Ophthalmic

Ophthalmology

Paediatrics

Pathology

Physiology

Plastic surgery

Preventive and social medicine

Psychiatry

Stomatology

Surgery

Training of doctors

Training of physicians

\section{Nursing and midwifery}

Assistant nursing

Basic nursing

Community nursing

General nursing

Gerontological services

Health care of old people

Health care of the disabled

Health care programmes

Hygiene, medical

Infant hygiene (nursing)

Midwifery

Mother craft nursing

Nursing

Nursing aide/Orderly

Psychiatric nursing

Specialised nursing
0914 Medical diagnostic and treatment technology

Ambulance service

Ambulance technology

Auditory prosthetics

Emergency para-medical technologies

Forensic medicine technology

Hearing aid technology

Medical laboratory technology

Medical technology

Nuclear medicine technologies

Optical lens making

Optical prosthetics

Optical technology

Orthopaedic prosthetics

Prosthetic technology

Radiography

Radiology technology

Radiotherapy

X-ray technology (medical)

\section{Therapy and rehabilitation}

Chiropractice

Dietician programmes

Massage (medical)

Mental health services

Nutrition and dietetics

Occupational therapy

Optometry

Osteopathy

Physiotherapy

Reflexology

Rehabilitation

Speech pathology and therapy

Vocational rehabilitation 
0916 Pharmacy

Dispensing pharmacy

Pharmacy

0917 Traditional and complementary medicine and therapy

Acupuncture and oriental medicine

Aromatherapy

Ayurvedic medicine

Herbalism

Herbology

Holistic medicine

Homeopathic medicine

Traditional medicine, for example Chinese

0919 Health not elsewhere classified

092 Welfare

0920 Welfare not further defined

0921 Care of the elderly and of disabled adults

Care (non-medical) of the elderly

Non-medical care of disabled adults

Personal care of adults

0922 Child care and youth services

Child care (non-medical)

Child recreation programmes

Day care

Non-medical care of disabled children

Youth recreation programmes

Youth services

Youth worker programmes

0923 Social work and counselling

Alcohol and drug abuse counselling

Alcohol, tobacco, drugs (knowledge about)

Career advising

Counselling
Crisis support

Family and marriage counselling

Maltreatment (knowledge about)

Mobbing (knowledge about)

Parole officer training

Probation officer training

Social care

Social policy

Social practice

Social theory (applied)

Social work (welfare)

Vocational counselling

Vocational guidance

0929 Welfare not elsewhere classified

098 Inter-disciplinary programmes and qualifications involving health and welfare

0988 Inter-disciplinary programmes and qualifications involving health and welfare

099 Health and welfare not elsewhere classified

0999 Health and welfare not elsewhere classified

10 Services

100 Services not further defined

1000 Services not further defined

101 Personal services

1010 Personal services not further defined

1011 Domestic services

Caretaking, housekeeping, home service

Chimney sweeping

Cleaning

Cooking (home)

Custodian/caretaker

Domestic science 
Dry-cleaning

Funeral services and mortuary science

Home economics

Laundry

Needlework (home)

Sewing (home)

Window cleaning

1012 Hair and beauty services

Barbering

Beauty therapy

Cosmetic services

Cosmetology

Fitness and weight control

Fitness services

Hairdressing

Make-up

Manicure

Massage (beauty)

Pedicure

Salon services (beauty therapy)

Wig making

1013 Hotel, restaurants and catering

Bar service

Bartender/mixologist

Catering

Cooking (restaurant and hotel-type)

Croupier training

Culinary arts

Fast food preparation

Food and hospitality services

Food serving

Hospitality services

Hotel and restaurant studies

Hotel receptionist training

Hotel services
Waiting and bar service

\section{Sports}

Bookmaking (horses etc)

Diving (sport)

Football playing

Gymnastics

Jockeying

Physical training (sports)

Sport leadership

Sport trainer studies

Sports

Sports coaching

Sports instructor training

Umpires and other sports officials

\section{Travel, tourism and leisure}

Abseiling (leisure)

Adventure based activities

Ground crew training (airports)

Guiding, tour leading

Leisure and tourism

Recreation and leisure

Recreation management

Tourism

Tourist trades

Travel agency services

Travel and tourism

Travel services

1019 Personal services not elsewhere classified

102 Hygiene and occupational health services

1020 Hygiene and occupational health services not further defined

1021 Community sanitation

Garbage disposal

Hygiene, community 
Hygienic standards

Refuse collection

Refuse/sewage disposal

Sanitation, community

Street cleaning

Water supply (service)

Waste management

1022 Occupational health and safety

Ergonomics (occupational health and safety)

Health and safety in the work place

Industrial welfare

Job safety

Labour protection

Labour security

Labour welfare (safety)

Occupational health and industrial hygiene

Occupational health and safety

Stress management

Work environment

1029 Hygiene and occupational health services not elsewhere classified

103 Security services

1030 Security services not further defined

1031 Military and defence

Army training

Defence studies

Military science

National security

Navy training

War theory

1032 Protection of persons and property

Civil security

Customs programmes

Diving (professional)
Fire-protection (fire-fighting)

Fire technology

Law enforcement

Life guarding

Police work

Policing studies

Prison work

Public security

Security and loss prevention services

Security guarding

1039 Security services not elsewhere classified

\section{Transport services}

\section{Transport services}

Air crew (flying and navigation)

Air traffic control

Air traffic safety

Aircraft operation

Aviation

Bus and coach driving

Cabin crew training

Communications (air, railway, road etc.)

Crane and truck driving

Driving training

Flying and navigation

Fork-lift truck driving

Mail operations

Nautical science

Navigation technologies

Postal services

Railway operations

Road motor vehicle operations

Seamanship

Seamen's programmes/qualifications

Ship operation 
Shipping

Stewardess/steward training (air)

Transport studies

Truck driving

108 Inter-disciplinary programmes and qualifications involving services

1088 Inter-disciplinary programmes and qualifications involving services
109 Services not elsewhere classified

1099 Services not elsewhere classified

99 Field unknown

999 Field unknown

9999 Field unknown 


\section{Appendix III}

\section{Alphabetical list}

\section{A}

1015 Abseiling (leisure)

0411 Accounting

0533 Acoustics

0215 Acting and directing

0542 Actuarial science

0917 Acupuncture and oriental medicine

0413 Administration

0415 Administrative and secretarial services

1015 Adventure based activities

0414 Advertising

0113 Adult literacy and numeracy teacher training

0716 Aeronautical engineering

0716 Aerospace engineering

0213 Aesthetics

0811 Agricultural business/agribusiness operations

0811 Agricultural economics

0811 Agricultural sciences

0811 Agriculture

0716 Agriculture machinery mechanics

0811 Agronomy and crop science

1041 Air crew (flying and navigation)

0712 Air pollution control

1041 Air traffic control

1041 Air traffic safety

0713 Air-conditioning programmes

0716 Aircraft engineering

0716 Aircraft maintenance

1041 Aircraft operation
0923 Alcohol and drug abuse counselling 0923 Alcohol, tobacco, drugs (knowledge about)

0541 Algebra

0914 Ambulance service

0914 Ambulance technology

0912 Anaesthetics

0531 Analytical chemistry

0912 Anatomy

0811 Animal breeding

0841 Animal health care

0811 Animal husbandry

0841 Animal reproduction (science)

0811 Animal training

0211 Animation

0541 Applied mathematics

0542 Applied statistics

0831 Aquaculture

0222 Archaeology

0731 Architectural urban design and planning

0731 Architecture

0322 Archival sciences

0031 Argumentation and presentation

1031 Army training

0917 Aromatherapy

0213 Art history

0213 Art studies

0213 Art theory

0841 Artificial insemination (of animals)

0912 Artificial insemination (of humans)

0619 Artificial intelligence

0031 Assertiveness training 
0913 Assistant nursing

0533 Astronomy

0533 Astrophysics

0532 Atmospheric sciences

0416 Auctioneering

0912 Audiology/hearing sciences

0211 Audio-visual techniques and media production

0411 Auditing

0914 Auditory prosthetics

0714 Automation

0716 Automotive electrical systems

0716 Automotive engineering

1041 Aviation

0716 Avionics

0917 Ayurvedic medicine

\section{B}

0912 Bacteriology

0721 Baking

0215 Ballet

0412 Bank teller studies

0412 Banking and finance

1013 Bar service

1012 Barbering

1013 Bartender/mixologist

0913 Basic nursing

0011 Basic programmes and qualifications

0021 Basic remedial programmes for youth or adults

0811 Basic skills in agriculture

1012 Beauty therapy

0721 Beer brewing

0310 Behavioural sciences

0715 Bicycle production
0715 Bicycle repair

0211 Binding and finishing (printing)

0711 Biochemical technologies

0512 Biochemistry

0512 Biological chemistry

0511 Biology

0511 Biometrics

0533 Biophysics

0512 Biotechnology

0711 Biotechnology engineering

0722 Boat building (non-motor)

0715 Boilermaking and welding

0211 Bookbinding

0411 Bookkeeping

1014 Bookmaking (horses etc)

0511 Botany

0721 Brewing

0732 Bricklaying

0732 Brickwork and masonry

0732 Bridge construction

0011 Broad generic (non-specialised) programmes and qualifications

0321 Broadcast journalism

0714 Broadcasting electronics

0732 Building construction

0731 Building design

0732 Building engineering

0732 Building maintenance

0732 Building renovation

0732 Building technology

1041 Bus and coach driving

0413 Business administration

0415 Business correspondence

0412 Business finance

0721 Butchery 
0416 Buying and selling

\section{C}

1041 Cabin crew training

0722 Cabinet making

0213 Calligraphy

0211 Camera operating

0722 Cane, willow and bamboo work

0912 Cardiology

0921 Care (non-medical) of the elderly

0921 Care (non-medical) of disabled adults

0922 Care (non-medical) of disabled children

0923 Career advising

1011 Caretaking, housekeeping, home service

0722 Carpentry (furniture)

0732 Carpentry and joinery (building)

0731 Cartography

1013 Catering

0511 Cell biology

0512 Cell technology

0732 Cement working

0214 Ceramics (craft)

0722 Ceramics (industrial)

0821 Charcoal burning

0721 Cheese production

0711 Chemical engineering

0533 Chemical physics

0711 Chemical process engineering

0531 Chemistry

0922 Child care (non-medical)

0922 Children recreation programmes

1011 Chimney sweeping

0915 Chiropractice

0215 Choreography
0211 Cinematography

0215 Circus

0731 City planning

0312 Civics

0732 Civil engineering

1032 Civil security

0113 Class teacher training

0231 Classical languages

1011 Cleaning

0415 Clerical programmes

0417 Clients' needs

0713 Climate engineering

0532 Climate research

0911 Clinical dentistry

0912 Clinical medicine

0723 Clothing industry

0723 Clothing trades

0723 Clothing, apparel and textile working

0031 Co-operation

0716 Coachwork

0724 Coal mining

0313 Cognitive sciences

0421 Commercial law

0321 Communication, mass- (wording and content)

1041 Communications (air, railway, road etc.)

0714 Communications equipment installation

0714 Communications equipment maintenance

0031 Communications skills

0714 Communications systems

0731 Community development

0913 Community nursing

0731 Community planning

0417 Company knowledge 
0232 Comparative literature

0211 Compositing (printing)

0215 Composition (music)

0211 Composition equipment operating

0612 Computer administration and

management

0714 Computer engineering

0211 Computer game production

0211 Computer graphics

0612 Computer media applications

0612 Computer network installation and maintenance

0613 Computer programming

0714 Computer repairing

0613 Computer science

0611 Computer software use

0612 Computer support

0613 Computer systems analysis

0613 Computer systems design

0211 Computer type-setting

0611 Computer use

0215 Conducting (music)

0721 Confectionery

0522 Conservation and land management

0214 Conservation of cultural material

0732 Construction equipment

0732 Construction plant operation

0732 Construction technology

0732 Constructional engineering

0732 Constructional metalwork (building)

0414 Consumer behaviour

1011 Consumer economics

0416 Consumer services

0313 Conversational therapy

0714 Control engineering
1011 Cooking (home)

1013 Cooking (restaurant and hotel-type)

0031 Co-operation skills

1012 Cosmetic services

1012 Cosmetology

0212 Costume design

0923 Counselling

0415 Court reporting

0214 Craft programmes

0214 Crafts, folk arts and artisan

0215 Creative and performance art

1041 Crane and truck driving

0232 Creative writing

0421 Criminal justice studies

0314 Criminology

0923 Crisis support

0811 Crop growing and husbandry

1013 Croupier training

1013 Culinary arts

0314 Cultural geography

0222 Cultural history

0314 Cultural studies

0322 Curatorial studies

0111 Curriculum development (theory)

0111 Curriculum studies

1011 Custodian/caretaker

0723 Custom tailoring

0417 Customer service training

1032 Customs programmes

0723 Cutting and tailoring

0912 Cytology

\section{D}

0721 Dairy foods (industrial)

0416 Dairy retailing 
0721 Dairy science

0215 Dance

0541 Data analysis (mathematics)

0415 Data entry

0714 Data processing technology

0612 Database administrator studies

0922 Day care (children)

0921 Day care (adults)

0214 Decorative metal crafts

0831 Deep sea fishing

1031 Defence studies

0314 Demography/population studies

0732 Demolition

0416 Demonstration techniques

0911 Dental assisting

0911 Dental hygiene

0911 Dental laboratory technology

0911 Dental nursing

0911 Dental science

0911 Dental surgery

0911 Dental technology

0911 Dentistry

0912 Dermatology

0212 Design

0212 Design of industrial products (artistic)

0211 Desktop publishing

0313 Development and child psychology

0031 Development of behavioural skills

0031 Development of mental skills

0031 Development of personal organisational capacities

0111 Didactics

0915 Dietician programmes

0714 Digital technology

0215 Directing (theatre)
0211 Disc jockey training

0916 Dispensing pharmacy

0111 Distance education methodology

0721 Distilling

1032 Diving (professional)

1014 Diving (sport)

0732 Dock and harbour engineering

0322 Documentation

0811 Dog breeding

1011 Domestic science

0215 Drama

0213 Drawing (artistic)

0732 Drawing, technical

0723 Dressmaking

0724 Drilling (industrial)

0114 Driver and safety teacher education

0114 Driving instructor training

1041 Driving training

1011 Dry-cleaning

\section{E}

0112 Early childhood teaching (within formal school settings)

0532 Earth science

0712 Ecological technology

0521 Ecology

0311 Econometrics

0311 Economic history

0311 Economics

0311 Economics, business

0321 Editing (newspapers)

0110 Education (not further defined)

0111 Education science

0111 Education technology 
0111 Educational assessment, testing and measurement

0111 Educational evaluation and research

0413 Educational management

0913 Elder care, health

0713 Electrical appliances repairing

0713 Electrical engineering

0713 Electrical fitting

0713 Electrical power generation

0713 Electrical trades

0714 Electronic data processing

0714 Electronic engineering

0714 Electronic equipment servicing

0113 Elementary teacher education

0215 Elocution

0214 Embroidery (craft)

0723 Embroidery and needlework (industrial)

0914 Emergency para-medical technologies

0413 Employment management

0712 Energy efficiency

0713 Energy studies

0031 Enhancing personal skills

0511 Entomology

0413 Entrepreneurship

0712 Environmental control

0712 Environmental engineering

0712 Environmental protection technology

0521 Environmental science

0912 Epidemiology

1022 Ergonomics (occupational health and safety)

0213 Etching (artistic)

0223 Ethics

0314 Ethnology

0732 Excavation engineering
0231 Exogenous languages

$\boldsymbol{F}$

0923 Family and marriage counselling

0031 Family life development training

0811 Farm and ranch management

0811 Farm maintenance

0811 Farming

0212 Fashion design

0215 Fashion modelling

1013 Fast food preparation

0214 Fibre, textile and weaving arts

0211 Film and video production

0211 Film and TV editing

0412 Finance

0412 Financial management

0213 Fine art printmaking

0213 Fine arts

1032 Fire-protection (fire-fighting)

1032 Fire technology

0232 First language studies

0831 Fish breeding

0831 Fish farming

0831 Fish husbandry

0831 Fishery science and technology

1012 Fitness and weight control

1012 Fitness services

0114 Flight instructor training

0732 Floor and wall tiling

0732 Floor covering

0812 Floriculture

0214 Floristry (flower arranging)

1041 Flying and navigation

0222 Folklore studies

0721 Food and drink processing 
1013 Food and hospitality services

0721 Food handling/hygiene

0721 Food preparation

0721 Food preservation

0721 Food processing industry

0721 Food science and technology

1013 Food serving

0721 Food techniques

1014 Football playing

0723 Footwear making

0231 Foreign languages (acquisition of)

0415 Foreign language secretary programmes

0912 Forensic medicine

0914 Forensic medicine technology

0912 Forensic pathology

0512 Forensic science

0821 Forest keeping

0821 Forest product techniques

0821 Forest ranging

0821 Forestry

1041 Fork-lift truck driving

0811 Fruit growing

0021 Functional literacy

1011 Funeral services and mortuary science

0723 Fur making

0722 Furniture crafts

0722 Furniture making

0723 Furrier

0314 Futurology

G

1021 Garbage disposal

0812 Gardening

0723 Garment production
0713 Gas distribution

0314 Gender studies

0912 General medicine

0913 General nursing

0011 General programmes and qualification with no specific subject emphasis

0511 Genetics

0512 Genetic code (DNA, RNA) studies

0512 Genetic engineering

0532 Geodesy

0532 Geographic information systems (GIS)

0532 Geography (nature)

0532 Geography (physical)

0314 Geography (social)

0532 Geoinformatics

0532 Geology

0532 Geomatics

0541 Geometry

0532 Geophysics

0532 Geoscience

0532 Geospatial technology

0913 Gerontological services

0912 Gerontology

0214 Glass arts and craft

0722 Glass production

0722 Glass working (industrial)

0732 Glazing

0214 Goldsmithing

0811 Goose keeping

0811 Grain growing

0211 Graphic design

0211 Graphic reproduction

0812 Greenhouse operations

0812 Green keeping

1015 Ground crew training (airport) 
1015 Guiding, tour leading

0715 Gunsmithing

1014 Gymnastics

0912 Gynaecology

H

0912 Haematology

1012 Hairdressing

0214 Handicrafts

0413 Health administration

1022 Health and safety in the work place

0913 Health care of the elderly

0913 Health care of the disabled

0913 Health care programmes

0914 Hearing aid technology

0713 Heating trades

0917 Herbalism

0917 Herbology

0716 Helicopter construction

0912 Histology

0222 History

0222 History and philosophy of science and technology

0213 History of art

0215 History of film and theatre

0421 History of law

0222 History of literature

0222 History of medicine

0215 History of music

0222 History of science and ideas

0222 History of technology

0917 Holistic medicine

1011 Home economics

0114 Home language teacher training

0917 Homeopathic medicine
0811 Horse breeding

0811 Horse husbandry

0812 Horticultural techniques

0812 Horticulture

1013 Hospitality services

1013 Hotel and restaurant studies

1013 Hotel receptionist training

1013 Hotel services

0732 House building

0314 Human geography

0412 Human resources management

0312 Human rights

0821 Hunting and trapping

0715 Hydraulics

0532 Hydrogeology

0532 Hydrology

1021 Hygiene, community

0913 Hygiene, medical

1021 Hygienic standards

I

0211 Illustration

0912 Immunology

0113 Indigenous crafts

0232 Indigenous language studies

0421 Indigenous law

0113 Indigenous teacher training

0732 Industrial abseiling (commercial)

0721 Industrial bakery/flour production

0212 Industrial design (artistic)

0722 Industrial diamond production

0712 Industrial discharge control

0417 Industrial relations

1022 Industrial welfare

0913 Infant hygiene (nursing) 
0613 Informatics (computer science)

0321 Information (wording and content)

0415 Information processing/data entry

0322 Information science

0322 Information searching

0612 Information technology administration

0612 Information technology security

0532 Inorganic chemistry

0732 Insulation

0412 Insurance

0211 Interactive media design

0212 Interior architecture

0212 Interior decorating

0212 Interior design

0912 Internal medicine

0311 International economics

0312 International relations

0611 Internet use programmes

0231 Interpretation programmes

0417 Introductory courses at work

0412 Investment analysis

0412 Investments and securities

0732 Irrigation and drainage (construction)

0811 Irrigation techniques

0421 Islamic sharia law

\section{$J$}

0214 Jewellery design

0214 Jewellery making (craft)

1022 Job safety

0031 Job-seeking programmes

1014 Jockeying

0732 Joinery and carpentry (building)

0321 Journalism

0421 Jurisprudence
K

0415 Keyboard skills

0723 Knitting (industrial)

\section{$L$}

0711 Laboratory assistant programmes

0711 Laboratory technician programmes

0711 Laboratory technology

0421 Labour law

1022 Labour protection

1022 Labour security

1022 Labour welfare (safety)

0731 Land surveying

0731 Landscape architecture

0812 Landscape gardening

0231 Language acquisition

0214 Lapidary and jewellery

1011 Laundry

0421 Law

1032 Law enforcement

0211 Lay-out

0723 Leather goods production

0723 Leather processing

0723 Leather trades

0421 Legal practice

0415 Legal secretary programmes

0421 Legal studies

1015 Leisure and tourism

0322 Librarianship training

0322 Library programmes

1032 Life guarding

0031 Life orientation programmes

0511 Life sciences

0511 Limnology 
0232 Linguistics, general

0021 Literacy

0021 Literacy and numeracy

0232 Literature

0222 Literature history

0213 Lithography

0413 Local public administration

0715 Locksmithing and safe repairing

0223 Logic

0821 Logging

0413 Logistic management

0113 Lower secondary teacher training

\section{M}

0311 Macro economics

1041 Mail operations

0812 Maintaining sports turf

1012 Make-up

0923 Maltreatment (knowledge about)

0413 Management of education

0413 Management science

0413 Management skills

0415 Management support services

1012 Manicure

0831 Mariculture

0716 Marine construction

0716 Marine engineering

0532 Marine science

0716 Maritime engineering

0414 Market research

0414 Marketing

0732 Masonry and tile setting

0321 Mass communication (wording and content)

1012 Massage (beauty)
0915 Massage (medical)

0542 Mathematical (theoretical) statistics

0541 Mathematics

0721 Meat processing

0715 Mechanical engineering

0715 Mechanical trades

0211 Media techniques

0914 Medical laboratory technology

0533 Medical physics

0912 Medical science

0415 Medical secretary programmes

0914 Medical technology

0912 Medical training

0912 Medicine

0222 Medieval and renaissance studies

0915 Mental health services

0414 Merchandising

0715 Metal casting and patternmaking

0715 Metal fitting, turning and machining

0715 Metal trades

0715 Metallurgical engineering

0715 Metallurgical technology

0532 Meteorology

0511 Microbiology

0715 Micromechanics

0913 Midwifery

1031 Military science

0724 Mineral technology

0532 Mineralogy

0724 Mining engineering

0724 Mining of minerals

0724 Mining technology

0923 Mobbing (knowledge about)

0511 Molecular biology

0223 Morals 
0913 Mother craft nursing

0716 Motorcycle engineering

0716 Motorcycle mechanics

0211 Multimedia production

0322 Museology

0322 Museum documentation

0322 Museum studies

0215 Music

0215 Music conducting

0214 Musical instruments (making, repairing and tuning)

0215 Musicology

0511 Mycology

\section{N}

0719 Nanotechnology

0311 National accounts

0522 National parks and wildlife management

1031 National security

0522 Nature conservation

0912 Naturopathic medicine

1041 Nautical science

0716 Naval engineering

1041 Navigation technologies

1031 Navy training

0214 Needle craft

1011 Needlework (home)

0612 Network administration

0612 Network design (computers)

0714 Network technology

0912 Neurology

0321 News reporting

0712 Noise pollution control

0421 Notary/Notary's practise

0914 Nuclear medicine technologies
0533 Nuclear physics

0713 Nuclear, hydraulic and thermal energy

0021 Numeracy

0541 Numerical analysis

0812 Nursery management (horticulture)

0913 Nursing

0913 Nursing aide/Orderly

0114 Nursing teacher training

0915 Nutrition and dietetics

0915 Nutrition science

\section{0}

0912 Obstetrics and gynaecology

1022 Occupational health and industrial hygiene

1022 Occupational health and safety

0915 Occupational therapy

0532 Ocean life sciences

0532 Oceanography

0911 Odontology

0415 Office automation

0413 Office management

0724 Oil and gas drilling

0724 Oil and gas extraction

0711 Oil refining

$0711 \mathrm{Oil} /$ gas/petrochemicals processing

0811 Olive growing

0912 Oncology

0613 Operating systems (IT)

0415 Operation of office machines

0541 Operational research

0912 Ophthalmology

0914 Optical lens making

0914 Optical prosthetics

0914 Optical technology 
0533 Optics

0915 Optometry

0911 Oral surgery

0811 Orchards construction

0531 Organic chemistry

0417 Organisation at work

0413 Organisational theory and behaviour

0812 Ornamental plant production

0511 Ornithology

0911 Orthodontics

0914 Orthopaedic prosthetics

0915 Osteopathy

\section{$\boldsymbol{P}$}

0912 Paediatrics

0111 Paedagogical sciences (education)

0213 Painting (art)

0732 Painting and wall covering

0532 Palaeontology

0716 Panel beating

0722 Paper manufacturing and processing

0421 Para-legal studies

0511 Parasitology

0031 Parenting courses

0923 Parole officer training

0721 Pastry cooking

0912 Pathology

0312 Peace and conflict studies

0831 Pearl cultivating

1012 Pedicure

0723 Pelt worker

0412 Pension insurance

0413 Performance appraisal

0215 Performing arts

0921 Personal care of adults
0031 Personal career planning

0031 Personal development

0031 Personal skills

0413 Personnel administration

0413 Personnel management

0531 Petrology

0512 Pharmacology

0916 Pharmacy

0232 Philology (first language)

0223 Philosophy

0213 Philosophy of art

0231 Phonetics

0211 Photo developing

0211 Photography

0114 Physical education teacher training

0531 Physical chemistry

1014 Physical training (sports)

0533 Physics

0912 Physiology

0915 Physiotherapy

0214 Picture framing

0811 Pig farming

0732 Pipe fitting

0533 Planetary sciences

0711 Plant and machine operation

(processing)

0732 Plastering (building)

0722 Plastic manufacturing

0912 Plastic surgery

0732 Plumbing

1032 Police work

1032 Policing studies

0311 Political economics

0312 Political history

0312 Political science 
0312 Politics

0531 Polymer chemistry

0031 Positive thinking

1041 Postal services

0811 Poultry husbandry

0713 Power production

0713 Power line installation and maintenance

0110 Practical paedagogical courses

0211 Pre-press operations

0112 Pre-primary teacher training

0715 Precision mechanics

0031 Presentation skills

0222 Preservation of artistic heritage

0912 Preventive and social medicine

0011 Primary level programmes and

qualifications

0113 Primary teaching (without subject specialisation)

0211 Print finishing and binding

0211 Printing

0211 Printing machining

1032 Prison work

0542 Probability theory

0923 Probation officer training

0711 Process technology

0812 Production of ornamental plants

0613 Programming (computer)

0613 Programming languages (Visual Basic, C++ etc.)

0613 Programming languages development

0416 Property sales

0914 Prosthetic technology

0913 Psychiatric nursing

0912 Psychiatry

0313 Psychoanalysis

0313 Psychology
0313 Psychotherapy

0413 Public administration

0413 Public and institution management

0312 Public policy studies

0414 Public relations

1032 Public security

0031 Public speaking

0321 Publishing (dissemination of messages)

0211 Publishing design

0416 Purchasing

0416 Purchasing, procurement and contracts

0541 Pure mathematics

\section{Q}

0417 Quality assurance

0413 Quality management

0732 Quantity surveying

0724 Quarry supervision

\section{R}

0811 Race horse care

0211 Radio and TV production

0914 Radiography

0914 Radiology technology

0914 Radiotherapy

1041 Railway operations

0724 Raw material extraction

0416 Real-estate business

0415 Receptionist training

0211 Recorded music production

1015 Recreation and leisure

1015 Recreation management

0413 Recruitment

0712 Recycling

0915 Reflexology 
0713 Refrigeration

1021 Refuse collection

1021 Refuse/sewage disposal

0314 Regional cultures

0915 Rehabilitation

0221 Religion

0221 Religious history

0221 Religious studies

0321 Reporting (news)

0416 Retailing

0732 Road building

1041 Road motor vehicle operations

0714 Robotics

0732 Roof fixing

0722 Rubber processing

0731 Rural development

0811 Rye and wheat growing

\section{S}

0221 Sacred books, study of

0723 Saddlery

0414 Sales and marketing

0416 Sales representatives

1012 Salon services (beauty therapy)

0732 Sanitation (building)

1021 Sanitation (community)

0732 Scaffolding work

0211 Screen printing

0213 Sculpture

0831 Sea food breeding

1041 Seamanship

1041 Seamen's programmes

0231 Second languages

0114 Secondary teaching

0415 Secretarial programmes
1032 Security and loss prevention services

1032 Security guarding

0532 Seismology

0031 Self-esteem skills

0031 Self-confidence

0231 Semantics, foreign languages

0232 Semantics, first language

1011 Sewing (home)

0723 Sewing (industrial)

0831 Shellfish breeding

0811 Sheep farming

0715 Sheet metal working

1041 Ship operation

0716 Shipbuilding

1041 Shipping

0723 Shoemaking and repairing

0415 Shorthand

0231 Sign language interpreting

0231 Sign languages

0214 Silversmithing

0031 Simple literacy

0213 Sketching (art)

0723 Skins and leather production

0314 Social anthropology

0923 Social care

0031 Social competence

0314 Social conflict theory

0314 Social geography

0412 Social insurance

0923 Social policy

0923 Social practice

0310 Social sciences

0923 Social theory (applied)

0923 Social work (welfare)

0314 Sociology 
0723 Soft furnishings

0613 Software development

0611 Software for calculating (spreadsheets), use of

0611 Software for data processing, use of

0611 Software for desktop publishing, use of

0611 Software for word processing, use of

0613 Software localisation

0613 Software programming

0613 Software testing

0522 Soil and water conservation

0811 Soil and water technician programmes

0811 Soil fertility

0811 Soil science

0713 Solar energy

0713 Solar power

0211 Sound and vision

0211 Sound techniques

0533 Space science

0113 Special education teaching

0913 Specialised nursing

0114 Specialised subject teaching

0232 Speech and rhetorical studies (first language)

0915 Speech pathology and therapy

0723 Spinning (industrial)

1014 Sport leadership

1014 Sport trainer training

1014 Sports

1014 Sports coaching

1014 Sports instructor training

0812 Sports grounds maintenance

0212 Stage designing

0413 Start your own business-courses

0542 Statistics
0715 Steel production

0415 Stenography

1041 Stewardess/steward training (air)

0412 Stock-broking

0416 Stock-keeping

0912 Stomatology

0214 Stone carving (craft)

0722 Stone cutting, precious

0732 Stonemasonry

1021 Street cleaning

1022 Stress management

0731 Structural architecture

0732 Structural engineering

0811 Sugar cane growing

0413 Supply change management

0912 Surgery

0542 Survey design

0542 Survey sampling

0731 Surveying

0415 Switchboard operating

0722 Synthetic fibre manufacturing

\section{$T$}

0723 Tailoring

0411 Tax accounting

0411 Tax management

0110 Teacher training

0112 Teacher training, pre-school

0113 Teacher training, primary

0113 Teacher training, lower secondary (without subject specialisation)

0114 Teacher training courses for university teachers

0114 Teacher training in arts and crafts

0114 Teacher training in commercial subjects 
0114 Teacher training in music

0114 Teacher training in nursing

0114 Teacher training in physical training

0114 Teacher training in second languages

0114 Teacher training in specific theoretical subjects (e.g. mathematics, history)

0114 Teacher training in technical subjects

0114 Teacher training in vocational subjects

0114 Teacher training with subject specialisation

0113 Teacher training without subject specialisation

0031 Teamwork

0732 Technical drawing

0114 Technical teaching

0710 Technology

0714 Telecommunication technology

0416 Telephone selling

0714 Television and radio repairing

0723 Textile techniques

0723 Textile trades

0723 Textiles, clothing and footwear

0215 Theatre

0221 Theology

0212 Three dimensional design

0722 Timber technology

0031 Time management

0512 Tissue culture technology

0721 Tobacco processing

0715 Tool and die making

0731 Topography

1015 Tourism

0731 Town and country planning

0512 Toxicology

0417 Trade union courses (general)

0917 Traditional medicine
0716 Train repair and maintenance

0413 Training management

0912 Training of doctors

0114 Training of driving instructors

0912 Training of physicians

0114 Training of trainers (with subject specialisation)

0113 Training of trainers (without subject specialisation)

0231 Translation programmes

1041 Transport studies

1015 Travel agency services

1015 Travel and tourism

1015 Travel services

0821 Tree felling

1041 Truck driving

0812 Turf cultivation

0812 Turf management

0211 Type-setting

0415 Typing

\section{U}

1014 Umpires and other sports officials

0723 Upholstery

0731 Urban planning

0731 Urban studies

V

0716 Varnishers/sprayers (vehicles)

0811 Vegetable plantation

0716 Vehicle and motor engineering

0716 Vehicle building

0716 Vehicle diagnostics

0716 Vehicle electrical systems

0716 Vehicle mechanics 
0716 Vehicle painting

0716 Vehicle repairing

0716 Vehicle trimming

0716 Vehicle varnishers/sprayers

0732 Ventilation (building)

0841 Veterinary assisting

0841 Veterinary medicine

0841 Veterinary nursing

0841 Veterinary science

0811 Vineyard construction

0512 Virology

0811 Viticulture

0923 Vocational counselling

0923 Vocational guidance

0915 Vocational rehabilitation

0532 Vulcanology

\section{w}

1013 Waiting and bar service

1031 War theory

0416 Ware-housing

1021 Waste management

0715 Watchmaking

0712 Water pollution control

1021 Water supply (service)

0732 Water supply and sewerage

engineering

0732 Water technology and engineering

0214 Weaving (craft)

0723 Weaving (industrial)

0612 Web design (Internet)

0715 Welding

0416 Wholesaling
1012 Wig making

0522 Wildlife management

0522 Wildlife ranger studies

1011 Window cleaning

0212 Window dressing

0713 Wind turbines

0811 Wine growing

0721 Wine production

0721 Wine science

0721 Wine storing/maturing

0314 Women's studies

0722 Wood machining and turning

0722 Wood technology

0214 Woodcarving

0722 Woodwork trades

0722 Woodworking and carpentry

0723 Wool science

0417 Work development

1022 Work environment

0417 Work place skills

0417 Working life

\section{$X$}

0914 X-ray technology (medical)

\section{$Y$}

0922 Youth recreation programmes

0922 Youth services

0922 Youth worker programmes

Z

0511 Zoology 